\title{
The Central Valley Project: Resource Development of a Natural Basin*
}

\author{
Leland O. Graham**
}

Water resources there are, if they can be captured and distributed over the land. From the highland barricade at the north the Sacramento River flows southerly, while from the Yosemite region at the southeast the San Joaquin River winds northeasterly until the two meet and consort in outlet to the sea through estuaries that connect with San Francisco Bay. These dominating rivers collect tribute from many mountain currents, carry their hoardings past parched plains and thriftlessly dissipate them in the Pacific tides. When it is sought to make these streams yield their wasting treasures to the lands they traverse, men are confronted with a paradox of nature; for the Sacramento, with almost twice the water, is accessible to the least land, whereas about three-fifths of the valley hes in the domain of the less affluent San Joaquin.

Mr. Justice Jackson, with these introductory words in the majority opinion in United States v. Gerlach Live Stock Co., ${ }^{1}$ recently has graphically and succinctly identified the foundation for a multitude of problems in the construction and operation of the gigantean Central Valley Project-problems which are engineering, economic, social, political, or legal, or which sometimes are admixtures of all.

To discuss even the legal implications of the Central Valley Project within the permissible compass of this article requires that some measure of selectivity of topics be einployed, else the treatment would be so general as to be of questionable interest and usefulness. The original Federal Reclamation Act was approved by President Theodore Roosevelt June 17, 1902.2 It has been amended, supplemented, and extended by 24 Congresses during the ensuing 48 years to a point

* This article is not intended as such to represent an official expression of the views of the Bureau of Reclamation or the Department of the Interior.

\#* Regional Counsel, Region 2, Bureau of Reclamation, Department of the Interior. The author has had the benefit of substantial assistance in the assembly and review of the manuscript of this article by E. Kendall Davis, Assistant Regional Counsel, and Helen T. Moss and John Robert Burton, attorneys on the staff of the Office of the Regional Counsel.

1339 U.S. 725, 728 (1950).

232 Stat. 388 (1902), 43 U.S. C. $\$ \S 372,373,381,383,391,392^{\circ}, 411,419,421,431$, $432,434,439,461,491,498$. 
at which the "Green Book," 3 which is a compilation of the statutory law and annotations of the judicial and administrative actions taken under it, now comprises 855 closely printed pages.

To bring an undertaking of the magnitude of the Central Valley Project imto operation and to continue to operate it presents novel and substantial problems of legal impact, federal or state, or both, in all stages. In the planning stage, probleuns of authorization, of construction and appropriations of funds to carry it forward are encountered; in the construction stage, water rights must be acquired or adjusted, reservoir and power plant sites and rights of way for canals and transmission limes must be acquired, and construction and supply contracts must be drafted and processed; and the effectuation of the entire program presents a continuing requirement that contracts for the disposition of the project's saleable products-water and electric powerbe negotiated and performed by all of the parties on bases adequate to insure revenues sufficient to return to the Federal Government the reimbursable portions of the project cost advanced by it.

The writer will endeavor to indicate the background of the Central Valley Project and then to identify and to describe, as empirically as possible, some of the primcipal legal problems which have attended its construction and operation. In so doing, it is hoped, it may be possible also to clarify certain unfortunately common misunderstandings of the interpretation and application of a number of provisions of the federal reclamation laws and of the national natural resource policies which they reflect.

\section{THE BACKGROUND}

\section{Prior to Federal Authorization}

The physical problem which the Central Valley Project is designed to solve is well identified in the majority opinion of the Court in the Gerlach cases. ${ }^{4}$ It is described in greater detail in the Costs Allocation Report on the Central Valley Project ${ }^{5}$ and in the Comprehensive Report of the Department of the Interior on the Central Valley Basin."

Numerous investigations and reports on the problem by federal

3 DePT. OF INTERTOR, Federax Reclamation Laws AnNotated (1943), with CumuIATIVE SUPpLEarent (1947). Additional reference compilations are Dept. OF INTERTOR, Bureat of Recratration Appropriation Acts and Artotments (1948) and Dept. of Intertor, Recramiation Project Feasibilitres aNd AUthorizations (1949).

${ }^{4}$ Suppra note 1.

5 H. R. Doc. No. 146, 80th Cong, 1st Sess. 8 (1947).

6 SEN. Doc. No. 113, 81st Cong., 1st Sess. 56-57 (1949). 
and state agencies preceded the adoption of the Central Valley Project, first by the State of California, and later by the United States. The first examination of the water resources of the Sacramento and San Joaquin Valleys was made pursuant to an authorization by the Congress to the War Department in 1873, ${ }^{\circ}$ which led to the so-called Alexander Report of February $1874 .{ }^{8}$ The next major study of these problems was begun in the 1890 's by Col. Robert Bradford Marshall, of the United States Geological Survey. The present Central Valley Project, while differing in certain detailed physical features, is a faithful reflection of the concept of the Marshall Plan. ${ }^{9}$

The next comprehensive plan for development was the State Water Plan, prepared by the Division of Water Resources of the California Department of Public Works, forwarded to the California Legislature in 1931, ${ }^{10}$ and approved and adopted by the Legislature in 1941 and

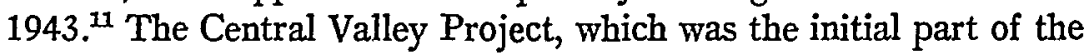
State Water Plan, was adopted by the Central Valley Project Act of 1933, passed by the California Legislature. ${ }^{12}$ A referendum on this Act, held December 19, 1933, resulted in its approval and in an au-

717 STAT. 622 (1873).

8 H. R. Exrc. Doc. No. 290, 43d Cong., 1st Sess. (1874).

9 Marshali, Irrigation of Twelve Mitlion Acres of LaNd in CatmFornia (1920). The introduction to this report states: "The people of California, indifferent to the bountiful gifts that Nature has given them, sit idly by waiting for rain, indefinitely postponing irrigation, and allowing every year millions and millions of dollars in water to pour unused into the sea, when there are hungry thousands in this and in other countries pleading for food and when San Francisco and the Bay Cities, the inetropolitan district of California, are begging for water .... My solution of the whole problem is to turn the Sacramento River into the San Joaquin Valley, a feat which is now shown to be practicable as an engineering enterprise that is possible of execution within ten years and that would justify a cost, if necessary, of $\$ 750,000,000$, be safe for the investor, present no legal obstructions, and provide for the present as well as the prospective land owner the inost attractive proposition ever offered in the State. Remember, however, that the plan is a big, State-wide plan and also remember that success, as California measures success, is assured only when the enterprise is planned and carried out in its entirety." Id. at 6,7 .

Unlike many others of vision and daring, Colonel Marshall hived to see his prediction vindicated through the construction of physical works and their initial operation. He died in San Francisco June 21, 1949. For an account of his career, see The Reclamation Era, January 1950, p. 7.

10 For a detailed review of the studies of the period 1900 to 1931, see Montcomerz and Crawson, History of Legiszation and Policy Formation of the Centrat Valuey Project 13-45 (Bureau of Agricultural Economics, Department of Agriculture, March 1946).

11 CaI. Water CODE $\$$ 10000-10002.

12 Cat. Stats. 1933, Ch. 1042, Cat. Water Code, Div. 6, Pt. 3. 
thorization for the issuance of revenue bonds in the amount of $\$ 170$,000,000 . However, unfavorable financial conditions required that the Central Valley Project, as a state undertaking, with financial assistance from the Federal Government, be abandoned in favor of its authorization and construction as a federal project under the federal reclamation laws. ${ }^{13}$

\section{Federal Authorization}

The first definitive federal action in recognition of the Central Valley Project came about with the enactment of the Rivers and Harbors Act of August 30, 1935,,$^{14}$ which "adopted and authorized" the prosecution of works in accordance with the plans recommended in a report of the Chief of Engineers. ${ }^{15}$ While this report recommended a nonreimbursable participation by the Federal Government in the construction of Kennett (Shasta) Dam to the extent of $\$ 12,000,000$, its approval did not constitute an appropriation of funds. The first funds became available September 10, 1935, when President Roosevelt, by a letter addressed to the Secretary of the Treasury, allocated $\$ 20,000$,$000^{16}$ from funds appropriated by the Emergency Relief Appropriation Act of $1935^{17}$ to the Department of the Interior for the initiation of construction of the Central Valley Project. This allocation was accompanied by an express proviso that ". . . the funds hereby allocated shall be reimbursable in accordance with the reclamation laws."

On November 26,1935, the Secretary of the Interior subnnitted to the President a feasibility report on the Central Valley Project, under Section 4 of the Act of June 25, 1910,18 and Subsection B of Section 4 of the Second Deficiency Act, Fiscal Year $1924 .{ }^{19}$ The engineering features recommended were generally similar to those set out

13 Hearings before House Committee on Appropriations on Interior Department Appropriation Bill for 1938, 75th Cong., 1st Sess. 1591-1592 (1937); id. 1940, 76th Cong., 1st Sess. 432-433 (1939) ; RoHrer and Decker, Water Resources Problems in CaIIroRNIA 27-31 (Bureau of Public Administration, University of California, 1949 Legislative Problems, No. 16).

1449 STAT. 1028, 1038 (1935).

16 House Ruvers and Farbors Conamttee Doc. No. 35, 73d Cong., 2d Sess. (1934). 16 This allocation ultimately was reduced to $\$ 4,200,000$.

1749 STAT. 115 (1935).

1836 STat. 836 (1910), 43 U.S. C. $\$ \$ 400,413$ (1946).

1043 STAT. 702 (1924), 43 U.S. C. $\$ 412$ (1946). Section 4 of this Act is commonly known as the "Fact Finders' Act," following the recommendations of a special committee appointed by the Secretary of the Interior. The committee's recommendations, commonly known as the "Fact Finders' Report," were printed as Ser. Doc. No. 92, 68th Cong., 1st Sess. (1924). 
In the Central Valley Project Act of 1933. The report concluded: "I . therefore recommend the approval of the Central Valley development as a Federal reclamation project." The President approved the report December 2, 1935..$^{20}$

The first direct appropriation of funds by the Congress for the Central Valley Project was contained in the Emergency Relief Appropriation Act of $1936,{ }^{21}$ which made available $\$ 6,900,000$, "to be reimbursable under the Reclamation Law . . . ."22

Section 2 of the Rivers and Harbors Act of 1937 provided in part: ${ }^{23}$

... That the entire Central Valley project, California ... is hereby reauthorized and declared to be for the purposes of improving navigation, regulating the flow of the San Joaquin River and the Sacramento River, controlling floods, providing for storage and for the delivery of the stored waters thereof, for the reclamation of arid and semi-arid lands and lands of Indian reservations, and other beneficial uses, and for the generation and sale of electric energy as a means of financially aiding and assisting such undertakings and in order to permit the full utilization of the works constructed to accomplish the aforesaid purposes: Provided further, That, except as herein otherwise specifically provided, the provisions of the reclamation law, as amended, shall govern the repayment of expenditures and the construction, operation, and maintenance of the dams, canals, power plants, pumping plants, transmission lines, and incidental works deemed necessary to said entire project, and the Secretary of the Interior may enter into repayment contracts, and other necessary contracts, with State agencies, authorities, associations, persons, and corporations, either public or private, including all agencies with which contracts are authorized under the reclamation law, and may acquire by proceedings in eminent domain, or otherwise, all lands, rights-of-way, water rights, and other property necessary for said purposes: And provided further, That the said dam and reservoirs shall be used, first, for river regulation, improvement of navigation, and flood control; second, for irrigation and domestic uses; and, third, for power. ${ }^{21}$

20 Dept. of Interior, Buread of Recladation Project Feasibitities aNd AUTHORIZATTONS 117-122 (1949).

21 This Act is Title II of the First Deficiency Appropriation Act, Fiscal Year 1936, 49 STAT. 1608 (1936).

$22 I d$. at 1622 .

2350 STAT. 844, 850 (1937).

21 It will be noted that the last proviso places navigation and flood control first in the order of purposes of the Project. Section 1(b) of the Flood Control Act of 1944, 58 STAT. 887, 889, bowever, provides that "... the use for navigation, in connection with the operation and maintenance of such works herein authorized for construction, 
Section 2 of the Rivers and Harbors Act of $1940^{25}$ amended the section quoted above by inserting the following additional authorizing language following the words "providing for storage and for the delivery of the stored waters thereof": ${ }^{26}$

... for construction under the provisions of the Federal reclamation laws of such distribution systems as the Secretary of the Interior deems necessary in connection with lands for which said stored waters are to be delivered ....

Beginning with the Interior Department Appropriation Act, $1938,{ }^{27}$ regular and deficiency appropriation acts have made funds available for the continuation of construction of the Central Valley Project, always "to be reimbursable under the reclamation law."

On October 14, 1949, the President approved H.R. 165, a bill reauthorizing the Central Valley Project "to include the American River development as hereinafter described, which development is declared to be for the same purposes as described and set forth in the Act of Congress of August 26, 1937."2s Under this act Folsom Dam and Reservoir will be constructed on the American River by the Department of the Army, and power plants, transimssion limes, and certain canals and diversion works will be constructed by the Department of the Interior. Upon the completion of the dam and reservoir, they will be transferred to the Department of the Interior for operation in integration $^{29}$ with the remainder of the Central Valley Project. ${ }^{30}$

of waters ... west of the ninety-eighth meridian shall be only such use as does not conflict with any beneficial consumptive use, present or future . . of such waters for domestic, municipal, stock water, irrigation, mining, or industrial purposes." One of the items "herein authorized" for construction by the Department of the Army is Iron Canyon Dam, on the Sacramento River, at a point only a few miles below Shasta Dam. While no funds have been appropriated for the construction of Iron Canyon, if the law ultimately requires that Shasta he operated first for navigation and Iron Canyon first for beneficial consumptive uses, a potentially interesting set of operational problems is suggested. A rationalization might be that Shasta releases for navigation purposes could be passed through Iron Canyon without constituting a "use for navigation" of the latter.

2554 StAT. 1198 (1940).

$28 \mathrm{Id}$. at 1200 .

2750 STAт. 564, 595 (1937).

23 Pub. L. No. 356, 81st Cong., Ist Sess.

20 Section 4 of the Act provides: "The Secretary of the Interior is directed to cause the operation of said works to be coordinated and integrated with the operation of existing and future features of the Central Valley project in such manner as will effectuate the fullest and most economic utilization of the land and water resources of the Central Valley project of California for the widest possible public benefit."

30 This is the first application of the "Folsom formula," identified by President Truman thus in his letter of August 15, 1949, to the Secretary of the Interior: "As addi- 


\section{The Comprehensive Plan}

It is important that the legal status of federal reclamation works planned for construction, authorized for construction and being constructed, not be confused. In a general way, the process may be said to pass successively through three stages: planning, authorization, and appropriation of funds for construction.

The presently authorized features of the Central Valley Project, some of which already are in operation, will be completed consistently with the appropriation of funds by the Congress. ${ }^{81}$ As a practical matter, of course, a naked authorization has no visibly tangible effectiveness until endowed by an appropriation of funds to carry it forward. ${ }^{39}$ Meanwhile, it serves as a parliamentary bulwark against a point of order in the consideration of an appropriation item. Those features which are presently authorized represent only the initial features, however, of a plan for the ultimate development of the Central Valley Basin, through many more dams, canals, power plants, and transmission lines, all of which would be coordinated engineeringly and financially into an integrated operation, thereby producing overall greater benefits at less cost than the sum of individual operations. The Comprehensive Report of the Department of the Interior on the Central Valley Basin was transmitted to the Congress by the Secretary of the Interior August 29, 1949,,$^{33}$ with the comments of the State of California, the Secretary of the Army, and other interested federal agen-

tional individual proposed projects not now authorized are found feasible on the basis of detailed project reports, they will be approved for authorization in accordance with the Folsom formula, i.e., multiple-purpose dams are the responsibility of the Bureau of Reclamation, and dams and other works exclusively for flood control are the responsibility of the Corps of Engineers." Supra note 6, at 5. An identical paragraph was included in a letter of the same date from the President to the Secretary of the Army. H. R. Doc. No. 367, 81st Cong., 1st Sess. vii (1949).

31 The primcipal so-called initial features consist of Shasta Dam and Reservoir and Keswick Dam and Reservoir, on the Sacramento; Friant Dam and Reservoir, on the San Joaquin; the Delta Cross Channel; the Contra Costa, Delta-Mendota, Friant-Kern, and Madera Canals; the Shasta and Keswick Power Plants; the Tracy Pumping Plant; the Delta Steam Plant; and a system of electric transmission lines. In addition to these there have now been authorized for construction the American River development features enumerated im Public Law 356, supra note 28-30, and the Sacramento Valley Canals, for which provision has just been made by Public Law ........, 81st Cong., 2d Sess. (Sept. 26, 1950).

32 This was notably demonstrated in the past in instances in which the Pacific Gas and Electric Company was successful in blocking appropriations of funds for the construction of electrical facilities already authorized. See REP. No. 899, SENATE CoMcMrTTEE on Appropritions, accompanying H. R. 4679, 78th Cong., 2d Sess. 2 (1944).

33 Supra note 6. 
cies. ${ }^{34}$ The Secretary of the Army transmitted that Department's report "on preliminary examinations and surveys of Sacramento-San Joaquin River Basin streams" to the Congress October 4, 1949, ${ }^{35}$ together with the comments of the State of California, the Secretary of the Interior, and other interested federal agencies. ${ }^{36}$ The two plans were accompanied by similar letters, dated August 15, 1949, from the President. ${ }^{3 T}$

At this point, the addition of further comprehensive features to the Central Valley Project as presently authorized presumably rests with the Congress. ${ }^{38}$

\section{WATER RIGHTS}

\section{The Plan of Project Operation}

The lack of balance between the water supplies and the irrigable acres of the Sacramento and San Joaquin Valleys should be kept in mind. Millerton Lake, formed by Friant Dam, stores a maximum of 521,000 acre-feet of the flow of the San Joaquim River, and will regulate floods. The stored water will be available for diversion 36 miles to the north, through the Madera Canal, which has an intake capacity of 1,000 cubic feet per second, and 153 miles to the south, through the Friant-Kern Canal, having a design capacity of 4,000 cubic feet per second. The impact of this operation on the continuation of the historical uses of the flow of the San Joaquin downstream from Friant is at once apparent. A program for adjustments of these downstream claims through negotiation has been actively prosecuted since $1939,{ }^{32}$

34 Section 1(c) of the Flood Control Act of 1944, supra note 24, had the effect of amending Section 9 (a) of the Reclamation Project Act of 1939, 53 STat. 1187, 1193, 43 U.S. C. $\$ 485 \mathrm{~h}$, to require that the Secretary of the Interior submit reports of plans to the Secretary of the Army and the affected state or states, and provides that, upon objection, the proposed works shall not be deemed authorized except upon approval by an act of Congress.

35 H. R. Doc. No. 367, 81st Cong., 1st Sess. (1949).

36 Section 1(a) of the Flood Control Act of 1944 imposes a procedural requirement on the Secretary of the Army similar to that imposed on the Secretary of the Interior by Section 1(c). Supra note 34 .

3r Supra note 30.

38 As a matter of law, individual features could be authorized without express legislative action upon compliance with the procedure prescribed by Section 9(a) of the Reclamation Project Act of 1939, supra note 34. This presumes, of course, that the plan and report of the Secretary of the Interior on the feature would receive no adverse comment from the State of California or the Secretary of the Army under Section 1(c) of the Flood Control Act of 1944, supra note 24.

30 With the exception of a six-month period immediately preceding the recent Gerlach decision, supra note 1 . See text infra at note 57. 
and will be subsequently described and related to the introduction of water from the Sacramento.

Shasta Dam and Reservoir, with a gross capacity of $4,500,000$ acre-feet, will regulate floods and store the surplus winter runoff of the Sacramento. This storage will be released to regulate the navigable flow of the river, satisfy valid irrigation requirements in the Sacramento Valley, repel tidal salinity imtrusions in the Sacramento-San Joaquin Delta, and provide water for domestic, irrigation, and industrial uses in the Delta and Bay areas. Surplus Sacramento River water, after being taken through the Delta Cross Channel, will be lifted 200 feet by the Tracy Pumping Plant into the Delta-Mendota Canal. ${ }^{40}$ This canal, which has an intake capacity of 4,600 cubic feet per second, will carry water 117 miles southward to Mendota Pool, where it will be used on large areas of San Joaquin Valley croplands to replace San Joaquin River water stored in Friant Reservoir for diversion north and south through the Madera and Friant-Kern Canals. The circuit is thus completed, and a water user at the end of the Friant-Kern Canal, near Bakersfield, may have water which would not have been available but for the release of water from Shasta Reservoir, 400 air-hine miles and many more water miles to the north.

\section{Acquisition of Water Rights on San Joaquin River}

While there is an almost inevitable tendency to describe the physical features of the Central Valley from north to south, beginning with Shasta Dam, the foregoing description of the plan of project operation makes it plain that the initial impact of the operation, in terms of private rights, is on the San Joaquin River and that, as an orderly next step, the Sacramento is brought in to relieve that impact.

In terms of magnitude, the logical beginning point in a review of the program of acquisition of San Joaquin water rights is with the so-called Miller \& Lux purchase and exchange contracts and deed. For many years, Miller \& Lux and its affiliated companies had initiated and developed extensive prescriptive and appropriative rights and had owned various parcels of land riparian to the river, its tributaries, branches, channels, and sloughs. It has been stated that at one time Miller \& Lux owned lands on both sides of the San Joaquin River for

40 Water released from Shasta Reservoir also will be used by the Shasta and Keswick power plants to generate electric power for the operation of project pumps and for commercial sales. 
a distance of more than 120 miles. ${ }^{31}$ It also owned many thousands of acres of nonriparian land.

Beginning about 1875 , a sand, rock, mud, and brush dam was constructed annually near the present site of Mendota Dam. The dam was washed out and replaced from year to year. Years later it was replaced by a wooden structure. Thereafter, the concrete-remforced structure now known as Mendota Dam was constructed. These dams formed Mendota Pool, from which water was taken through canals to both riparian and nonriparian land. The second principal point of diversion was at "Sack Dam," so named because it was rebuilt for many years with brush and sacks of sand, at the head of Temple Slough, which branches off the west side of the river at a point about fourteen miles downstream from the Mendota Dam. Many water rights actions were brought by and against Miller \& Lux over a period of years. By a sustained and diligent policy, Miller \& Lux developed and maintained its highly valuable prescriptive and appropriative rights. At the same time, it kept its riparian rights. Included in the protracted litigation was an action instituted by Miller \& Lux against the Madera Irrigation District and others in Fresno County. ${ }^{42}$ For many practical purposes, this case involved nearly a complete adjudication of rights to the use of the flows of the San Joaquin River above Temple Slough. The decision is commonly known as one of the "Haines decrees," after the trial judge, Charles C. Haines.

In 1939, after extended negotiations, a transaction was concluded between the United States and Miller \& Lux and its affiliated companies through the execution of the purchase and exchange contracts and deed, all of which may be considered as one instrument for legal purposes. ${ }^{43}$ They in effect expressed the consent of Miller \& Lux and its affiliated companies to the operation of Friant Reservoir in accordance with prescribed standards and conveyed certain defined rights. In return, the United States paid a cash consideration of $\$ 2,450,000^{44}$ and contracted to furnish, for certain croplands, water of a stipulated

\footnotetext{
41 Treadweyt, The Cattue Knvg 63 (Rev. ed. 1950).

42 Miller \& Lux, Inc. v. Madera Irrigation District, Superior Court, Fresno County, No. 25729 (1933).

43 These documents were recorded in September 1939.

44 Prior to the execution of these contracts, Miller \& Lux had sold some of its vast holdings. In the conveyances of these lands, it reserved water rights to itself by different forms of reservations. The purchase contract with the United States included these reservation rights. However, $\$ 511,350$ was placed in escrow pending a determination of the validity of these rights. The validity of some of the reservations was passed upon in the Gerlach case, supra note 1.
} 
quantity and quality in substitution for a portion of the San Joaquin water which would be available but for the operation of Friant Reservoir.

The Madera Irrigation District owned the Friant Dam site, certain water rights, and portions of the reservoir area. On May 24, 1939, the United States entered into a contract with the district, under which the United States purchased the water rights and real property of the district for $\$ 300,000$ and agreed to deliver water to the district under certain conditions. Under the contract, and the deeds made in pursuance thereof, it appears that the United States succeeded to all of the interests necessary to be obtained, in so far as the district was concerned, for the planned operation of the Central Valley Project. Among other interests to be transferred to the United States under it were the rights to all of the district's filings and permits to appropriate water. ${ }^{45}$

Other large land owners with whom the United States negotiated water right adjustment contracts included Chowchilla Farms, Inc., Edison Securities Company, as owner of the Herminghaus Ranch, ${ }^{46}$ and some fourteen owners along the east side of the San Joaquin River between Chowchilla Farms and Stevinson Colony.

There are approximately 230 small land holdings on the 37-mile reach of the river immediately below Friant Dam and extending to a point slightly below the Gravelly Ford Canal. It is planned to leave an adequate water supply in the river throughout this area, so that irrigation may be continued upon a basis consistent with reasonable use by all water users. The plan in some instances, however, will interfere with water uses and the availability of water and will necessitate changes in the methods of diversion. In negotiating with the landowners in this area a committee was formed in accordance with a recommendation by the Commissioner of Reclamation to the Secretary of the Interior, approved January 15, 1941, concerning the Friant-toGravelly Ford negotiations. The committee examined each holding, considered the character of the land involved, the methods of diversion and use of water, the plan of operation of Friant Reservoir, the existence of reservations of water rights which the United States had

45 The contract was recorded March 4, 1940.

46 The water rights of the owner's predecessor in title were the subject of litigation in Herminghaus v. Southern California Edison Co., 200 Cal. 81, 252 Pac. 607 (1926), cert. denied, 275 U.S. 617 (1927), the decision which gave to riparian rights such an overriding stature as to bring about an amendment of the California constitution, Article XIV, Section 3, adopted November 6, 1928. 
already purchased from Miller \& Lux, and such other matters as would affect the value of the interests to be taken. As for the holdings wherein it was found that there would be an invasion of rights by reason of project operations, the committee appraised the value of the estate taken or to be taken and recommended that contracts be offered by the United States to the owners. These contracts provide for cash payments and, in some instances, for the construction by the United States of certain irrigation facilities or the performance of channel work for control of the river. ${ }^{4 \pi}$ The negotiation program in the Friant-to-Gravelly Ford area is close to completion and, while nineteen holdings are in litigation, ${ }^{48}$ it seems to have been generally regarded as a program equitably conducted..$^{49}$

In addition to acquisition of water rights on the San Joaquin River through direct negotiation, the United States has acquired by assign-

47 Contrary to some impressions, the operation of Friant Reservoir will not "dry up" the San Joaquin River. But its operation will in instances affect the customary operations of downstreain users to an extent which is regarded as compensable. The following is a ustal provision in contracts in this area: "The United States recognizes that the Contracting Owners have certain rights to the use of water from, or influenced by, the River on or in connection with said land, either by appropriation, or by prescription, or as owners of land overlying an underground water supply whether from an underground stream or from percolating water, or as owners of land riparian to the River, or otherwise, and in full satisfaction of said water rights howsoever acquired, claimed, or enjoyed the United States will permit water to pass by or through Friant Dam into the River, which water, together with accretions to the River from all sources whatsoever, will maintain a live stream in the River at the control point hereinafter defined." Also see infra note 49.

48 There are 19 holdings, 15 plaintiffs, 16 suits, and three courts. One case is in the United States Court of Claims and involves two holdings. There are 14 separate suits in the United States District Court for the Southern District of California and one suit in the United States District Court for the District of Columbia. An opinion on preliminary motions in several of these cases was rendered April 13, 1950, in Rank v. Krug, 90 F. Supp. 773 (1950).

49 In a hearing held May 16, 1950, in Rank v. Krug, No. 685 ND, in the United States District Court for the Southern District of California, counsel for the Irrigation Districts Association of Califorma stated that he represented "some 10 or 12 of those water users and that I got them to sign the contract with the Bureau of Reclamation which gave to those people ... what I considered to be the nlost perfect water right in the State of Califorma." Counsel went on to say: "That contract provided that the Bureau of Reclamation would release enough water from Friant Dam so that there would be a surface flow of 5 second-feet of water at least at their lower boundary of their properties, 30 miles down the last user down there would have a surface flow of 5 secondfeet of water minimum by his property. To have a surface flow in the San Joaquin of that amount you have to keep the ground water recharged, otherwise you wouldn't have a surface flow." Reporter's Transcript, p. 224. 
ment certain applications filed by the California Director of Finance ${ }^{50}$ for power generation and storage and diversion for irrigation, domestic use, and flood control on the San Joaquin. ${ }^{51}$ The United States also filed its own application ${ }^{62}$ in 1944 for the diversion of 5,000 cubic feet per second from Fresno Slough. This application is of substantial significance in the ultimate operation of Pine Flat Reservoir, on the Kings River.

\section{The Gerlach Decision}

Logically and geographically the recent Gerlach decision of the United States Supreme Court, ${ }^{53}$ which affirmed six judgments of the Court of Claims against the United States, should be considered under the preceding heading, since it arose out of the use of the overflow of the San Joaquin River on grasslands. However, it is of such moment as to suggest a landmark decision in the administration of federal reclamation projects in California and therefore will be discussed separately.

Presumably the principal point of general legal interest with respect to the reclamation projects in the decision is the rejection of the "paramount rights theory." The Solicitor General contended that the project was authorized by the Congress, under the commerce power, as in aid of navigation and flood control and therefore that no enforceable obligation to make compensation existed. The case was first heard by the Court in March 1949. Before the end of the term the Court ordered it reargued at the October 1949 term. It was reached in March 1950. Shortly after the reargument the Clerk of the Court addressed the Solicitor General, stating:

The Court desires to be advised whether the Secretary of the Interior in the construction of irrigation projects has construed section 8 of the Reclamation Act of 1902 to include rights in navigable as well as non-navigable streams and has proceeded under section 7 to acquire those rights.

This request was informally referred to the Department of the Interior and an extended review of the history of the administrative practice of the Bureau of Reclamation under the Reclamation Act of $1902,{ }^{54}$ in the form of a memorandum from the Commissioner of Rec-

50 Under Cat. Water CODE $\$ 10500$.

51 Applications Nos. 5638, 5639, and 9639 were assigned by the Director of Finance to the United States September 30, 1939.

52 Application No. 10750, filed January 7, 1944.

53 Supra note 1.

54 Supra note 2. 
lamation to the Solicitor of the Department of the Interior, was forwarded to the Solicitor General and by him to the Court.

To the extent that the bases of the Court's June 5 decision can be literally localized in the majority opinion, the following paragraphs are suggested as significant: ${ }^{55}$

Even if we assume, with the Government, that Friant Dam in fact bears some relation to control of navigation, we think nevertheless that Congress realistically elected to treat it as a reclamation project. It was so conceived and authorized by the President and it was so represented to Congress. Whether Congress could have chosen to take claimants' rights by the exercise of its dominant navigation servitude is immaterial. By directing the Secretary to proceed under the Reclamation Act of 1902, Congress elected not "to in any way interfere with the laws of any State ... relating to the control, appropriation, use, or distribution of water used in irrigation, or any vested right acquired thereunder." 32 Stat. 388, 390.

We cannot twist these words into an election on the part of Congress under its navigation power to take such water rights without compensation. In the language of Mr. Justice Holmes, writing for the Court in International Paper Co. v. United States, 282 U.S. 399, 407 , Congress "proceeded on the footing of a full recognition of [riparians'] rights and of the Government's duty to pay for the taking that [it] purported to accomplish." We conclude that, whether required to do so or not, Congress elected to recognize any statecreated rights and to take them under its power of eminent domain.

We are guided to this conclusion by the interpretation placed on Congress' Acts by the Reclamation Bureau, which, in administering the project, has at all times pursued a course impossible to reconcile with present contentions of the Government. From the beginning, it has acted on the assumption that its Friant undertaking was a reclamation project. Even a casual inspection of its committee hearings and reports leaves no doubt that Congress was familiar with and approved this imterpretation. Although the Solicitor General contends that because of the navigation purpose remotely involved deprivation of water rights along the San Joaquin is not compensable, we have observed that the plan as originally adopted and as carried out by the Bureau included replacement at great expense of all water formerly used for crops and "controlled grass lands" and purchase of that used on marginal pasture lands. It lias consistently advised the Congress that it was purchasing San Joaquin water rights and appropriations liave been made accordingly. Moreover, Congress and the water users have been advised that in prosecution of the work, existing water rights would be respected. 
During the latter part of 1945 , the Department of Justice had recommended the cessation of further negotiations toward the acquisition of water rights from the owners of lands similarly situated to those in litigation. Subsequently the "second group of Gerlach cases" were filed in the Court of Claims, and judgments for the plaintiffs were entered July 10, 1950. In November 1949, the Department of Justice requested the Department of the Interior to suspend the closing of further water right settlements in the Central Valley pending a final decision in the Gerlach cases. The closing of all further settlements, including those remaining in the Friant-to-Gravelly Ford area, thereupon was suspended. Immediately upon the Court's decision of June 5, however, the closing of settlements in this area was resumed and they are now substantially completed with respect to all those owners who have been willing to negotiate. ${ }^{57}$

It is not within the province of this article to speculate on the ultimate scope of the application of the Court's decision. It seems reasonable to suppose, however, that the way is now open for disposition in due course, through trial or otherwise, of other suits the handling of which has been held up pending the Gerlach decision. ${ }^{\text {ts }}$

\section{The Sacramento River}

The operational situation on the Sacramento River is quite different from that on the San Joaquin. The problems of the latter have just been described in terms of the impoundinent of substantially all of the flow of the river, ${ }^{59}$ its diversion north and south from the storage reservoir, and the introduction of Sacramento River water, via the

56 Gerlach Live Stock Co. v. Umited States, No. 47601; McNamara v. United States, No. 47602 ; Potter v. United States, No. 47603; Solari v. United States, No. 47604.

$\boldsymbol{5 7}$ In connection with the litigation in this area, the Irrigation Districts Association of California recently published a brochure entitled "Whose Water?", which is No. 16 of a series. The document quotes copiously from Judge Hall's opinion of April 13, 1950, in Rank v. Krug, and four related cases, supra notes 49-49. By reason of a nice selectivity in the employinent of heavy black type, an otherwise uninformed reader might be led to conclude that the plaintiffs liad prevailed. In fact, the defendant's motion to dismiss was granted in one case and, while the defendants' motions to dismiss were denied in four cases, the plaintiffs' motions for an interlocutory imjunction with respect to the operation of Friant Reservoir also were denied. The cases now await trial.

5s In addition to the litigation described supra at note 48 there are some 21 suits in the Court of Claims, 17 of which involved the lands lying below the nouth of the Merced River, and in all of which the basic issue is the fact or the extent of damage. None has proceeded to a hearing.

60 Except as described supra notes $47,49$. 
Delta-Mendota Canal, in substitution. The Sacramento, on the other hand, will have its flow regulated for navigation and will act as a natural conduit for the conveyance of water to be distributed in the operation of the Project.

On July 30, 1927, the California Director of Finance filed Applications Nos. 5625 and 5626 for the appropriation of Sacramento River water. ${ }^{00}$ In addition, on August 2, 1938, the Director of Finance filed Applications Nos. 9364 and 9365 for the appropriation of Sacramento River water. ${ }^{61}$ These applications were assigned to the United States September 3, 1938.

The Bureau of Reclamation is now engaged in an intensive investigation of the service area of the Sacramento River. This investigation includes title checks to determine the status of riparian holdings, assembly, through a cooperative agreement with the California Division of Water Resources, of data on water diversions, uses, and returns, for the purpose of determining net depletion, and a survey of crops grown in the service area. The ultinuate objective of the investigation, it is to be emphasized, does not involve a concept of settlement of water rights as among private users. It rather is to ascertain the facts which, according to accepted legal standards, provide the bases for a computation of the past and present entitlements for the reasonable and beneficial use of water and hence for the relationship of these entitlements to the legal rights of the United States.

\section{THE ACREAGE LIMITATION}

\section{History}

The so-called "160-acre limitation," "acreage limitation," or "excess-land limitation" has, since 1944, been one of the principal battle-

60 Under CAL. WATER CODE $\$ 10500$. No. 5625 is for the appropriation of 11,000 cubic feet per second and 3,190,000 acre-feet per annum for the generation of power at Shasta Dam. Application No. 5626 is for the appropriation of 8,000 cubic feet per second and storage of $3,190,000$ acre-feet per annum, at Shasta, and for distribution of it on the floors of the Sacramento and San Joaquin Valleys for domestic and irrigation uses, salinity repulsion, flood control, and navigation purposes.

61 Under CAx. WATER CODE $\$ 10500$. No. 9364 is for the appropriation of 9,000 cubic feet per second and storage of 3,000,000 acre-feet per annum for irrigation and domestic uses, salinity and flood control, and navigation purposes. The points of diversion were stated to be along the Sacramento River from Shasta Dam to the Sacramento-San Joaquin Delta and along the Delta channels. Application No. 9365 is for the diversion of 7,000 cubic feet per second and storage of 3,310,000 acre-feet per annum for the generation of power at Shasta Dam. 
grounds of the opponents and proponents of federal development of natural resources in the Central Valley. ${ }^{62}$

All three terms are unhappy accidents of nomenclature, but they have become such casual and convenient symbols of verbal shorthand that any effort to encourage the employment of a more realistic identification, such as "project water limitation," would seem quixotic. They are unrealistic in that they seen to imply that the law has said something about how much land one nay own. The limitation neither legally nor factually is one on the ownership of land-it rather is one on the amount of the owned land which may receive water from a federal reclamation project. Nor does it go in any way, as is so often asserted, toward regulating what a landowner does with whatever water supply he already may have.

The acreage limitation provisions of the federal reclamation laws are not new. The first such provision of general application appeared in Section 5 of the original Reclamation Act of $1902 .^{63}$ The most recent enactment of general application ${ }^{64}$ is Section 46 of the Omnibus Adjustment Act of May 25, 1926. ${ }^{\circ}$ This particular federal statute is the one applicable to the Central Valley Project, and the inclusion of its requirements in water service and repayment contracts with irrigation districts ${ }^{66}$ in the Central Valley therefore is a mandate by

62 The campaign to repeal this 48 -year old statutory principle seems to be quiescent at the moment, and there are indications that the front bas shifted. See discussions headed "Water Rights" supra, "Power" infra, and "The Kings River Controversy" infra.

63 As codified, this section provides: "No right to the use of water for land in private ownership shall be sold for a tract exceeding one hundred and sixty acres to any one landowner, and no such sale shall be made to any landowner unless he be an actual bona fide resident on such land, or occupant thereof residing in the neighborhood of said land, and no such right shall permanently attach until all payments therefor are made." 43 U.S. C. $\$ 431$ (1946). Subsequent enactments contained similar provisions. See e.g., 36 STAT. 925, 926 (1911), 43 U.S.C. $\$ 524$ (1946) ; 37 STAT. 265, 266 (1912), 43 U. S. C. $\$ \S 543,544$ (1946); and 38 STAT. 686, 689 (1914), 43 U.S. C. $\$ 418$ (1946).

61 Other acreage limitation provisions, primarily of historical import or of special application to particular projects, are found in 34 STAT. 519 (1906), 43 U.S. C. $\$ 434$ (1946) ; 36 StaT. 592 (1910), 43 U.S.C. \$ 441 (1946); 39 STAT. 506, 508 (1916), 43 U.S.C. $\$ 627$ (1946); 52 Stat. 211 (1938), 43 U.S. C. $\$ 600$ a (1946) ; 54 Stat. 1119, 1122 (1940), 16 U.S.C. \$590z-2(c) (5) (1946); and 57 STAT. 14, 15 (1943), 16 U. S. C. $\S 835$ a (1946). Section 5 of the Reclaination Act of 1902, supra note 2, has been held by the Solicitor of the Department of the Interior to be inapphicable to projects established under 54 STAT. 1119, supra, on the ground that the latter act embodies excess-land provisions of its own. Solicitor's Opinion M.34062, August 9, 1945.

6544 STAT. 636, 649-650 (1926), 43 U.S.C. $\$ 423 \mathrm{e}$ (1946).

66 For convenience, the term "irrigation district" is used generally througlout this article in a generic sense, to denote all forms of water users organizations eligible to contract with the United States. California has thirty-five general district acts, in ad- 
the Congress, and not open to a bargaining process during contract negotiations.

Section 46 provides in part:

No water shall be delivered upon the completion of any new project or new division of a project until a contract or contracts in form approved by the Secretary of the Interior shall liave been made with an irrigation district or irrigation districts organized under State law providing for payment by the district or districts of the cost of constructing, operating, and maintaining the works during the time they are in control of the United States, such cost of constructing to be repaid within such terms of years as the Secretary may find to be necessary, in any event not more than forty years from the date of public notice hereinafter referred to, and the execution of said contract or contracts shall have been confirmed by a decree of a court of competent jurisdiction .... Such contract or contracts with irrigation districts hereinbefore referred to shall further provide that all irrigable land held in private ownership by any one owner in excess of one liundred and sixty irrigable acres shall be appraised in a manner to be prescribed by the Secretary of the Interior and the sale prices thereof fixed by the Secretary on the basis of its actual bona fide value at the date of appraisal without reference to the proposed construction of the irrigation works; and that no such excess lands so held shall receive water from any project or division if the owners thereof shall refuse to execute valid recordable contracts for the sale of such lands under terms and conditions satisfactory to the Secretary of the Interior and at prices not to exceed those fixed by the Secretary of the Interior; and that until one-half the construction charges against said lands shall have been fully paid no sale of any such lands shall carry the right to received water unless and until the purchase price involved in such sale is approved by the Secretary of the Interior and that upon proof of fraudulent representation as to the true consideration involved in such sales the Secretary of the Interior is authorized to cancel the water right attaching to the land involved in such fraudulent sales ....

The "First 160 Acres"

A common misconception of the meaning and application of the federal proscription is that anyone owning more than 160 acres of land

dition to a number of special acts creating individual districts, such as the Santa Barbara County Water Agency Act. CAL. Stats. 1945, c. 1501, as amended by CaL. Stats. 1949, c. 12. An excellent and useful comparative review of the provisions of all of these acts, entitled General Comparison of California Water District Acts, was issued by the State Division of Water Resources in May 1950. In addition to districts organized under the Irrigation District Law (CAx. WATER CODE, Div. 11), the Bureau of Reclamation thus far has contracted with or is negotiating with water districts, county water districts, municipal utility districts, public utility districts, and water storage districts. 
is, ipso facto, ineligible to receive project water. ${ }^{07}$ A somewhat vaguely expressed extension of this misconception is that anyone owning more than 160 acres is entitled to no water from any source, ${ }^{68}$ even if he has a right which has ripened into the dignity of recognition under state law. The latter expression is not, of course, accompanied by anything in the nature of constitutional considerations of just compensation. It seems sufficient to observe that there is nothing in the federal law which even purports to provide for the regimentation of a landowner's use of his own water supply, the right to the use of which is recognized under the state law. Moreover, Section 8 of the Reclamation Act of $1902^{69}$ is quite explicit in honoring the continued enjoyment of private water rights which have vested under state law.

As for the eligibility of an excess-land owner to receive project water, it should be noted that Section 46 of the Omnibus Adjustment Act merely requires that contracts with irrigation districts include provisions which obligate the districts to furnish no project water to excess lands " if the owners thereof shall refuse to execute valid recordable contracts for the sale of such lands ...." Stated conversely, the owner of 1,600 acres, or 16,000 for that matter, may receive project water from an irrigation district for all of his acres if he is willing to execute a contract agreeing to sell all in excess of 160 .

A more probable and certainly more realistic problem is presented in the situation of a single owner of say 200 acres, who wants project water but who is disinclined to agree to any reduction of his holding in any circumstances. This question arose in 1945 during the negotiation, in the Central Valley Project, of the first 40-year water service

67 A fair sample of such loose talk appeared in Mr. Ray Tucker's syndicated column, entitled News Betind the News, in the October 28, 1947 issue of The Sacramento Bee. Mr. Tucker stated that "the federal reclamation law provides not a drop of the impounded and hoarded water shall be allotted to any farm consisting of more than 160 acres." A more recent example is reflected at page 26 of the June 5, 1950 issue of Newsweek. In commenting on the views of a California aspirant to the United States Senate it was stated that "he wants to repeal the law which says that no farm larger than 160 acres shall receive water from a Federal canal." Whatever the candidate's views in fact are, there is much less of a job of repealing the acreage limitation open for the Congress than this statement would suggest.

68 In Mr. Tucker's column, supra note 67, he deplored the plight of the "many old settlers" who "added to their holdings until now they may have 600 acres or more," and he concluded, with more perspiratory vividness than legal accuracy: "As the statute now stands, they must reduce their farms to 160 acres by selling land which they have saved and sweated for-or be deprived of water." The law is considerably less demanding than this.

69 Supra note 2. 
contract under the authority of Section $9(e)$ of the Reclamation Project Act of $1939 .{ }^{70}$ The then Acting Regional Counsel rendered an opinion, dated August 1, 1945, to the Commissioner of Reclamation, to the effect that a contractual provision which would permit the district to deliver water to the "first 160 acres," only, of an excess-land owner would not be inconsonant with Section 46, notwithstanding the lack of execution of a recordable contract to sell the excess. ${ }^{71}$ This

To Contract between United States and Southern San Joaquin Municipal Utility District, for water service from Friant-Kern Canal, dated October 18, 1945.

71 The following is quoted from the opinion: "Two considerations lead me to this conclusion. One is what to me seems to be the plain language of the statute, read by accepted grammatical principles, and the other is the administrative construction which appears to have been placed on it. The statute first requires that irrigable land held by any one owner 'in excess of one hundred and sixty irrigable acres' be appraised in a certain nuanner; it next prescribes that no such excess land 'shall receive water' lacking a valid recordable contract for the sale of such land on certain terms. That there is no prohibition of the delivery of water to the 'first 160 acres' thus seems clear at the outset, since the prescription is addressed only to 'such' excess lands, and the only lands which could be 'excess' would be those other than the first 160 acres."

In evaluating the administrative interpretation of Section 46, reference was made to the provisions of five contracts previously executed in other federal reclamation projects: Vale Irrigation District, Vale Project, Oregon (1926); Casper-Alcova Irrigation District, Kendrick Project, Wyoming (1935); Northern Colorado Water Conservancy District, Colorado-Big Thompson Project, Colorado (1935); Jefferson Water Conservancy District, Deschutes Project, Oregon (1938); Lugert-Altus Irrigation District, W. C. Austin Project, Texas (1942).

Finally, attention was given also to the so-called "Barnes Questionnaire," which comprised a series of questions submitted by Mr. Harry Barnes, Chairman of the Central Valley Committee of the Irrigation Districts Association of Califorria, and included the following: "Referring further to the excess land limitations of the Reclamation Law. Assume a private landowner has 200 acres in the Project. That means 40 acres of excess land. Under the Reclamation Law is the landowner permitted to receive water on 160 acres and leave the 40 acres of excess land dry without entering into any agreement with the Bureau of Reclamation relative to the disposition of the 40 acres, or is he required to enter into an agreement regarding the disposition of the 40 acres of excess land before he is permitted to secure water on 160 acres of nonexcess land?" The regional director of the bureau replied thus, in a letter dated July 18, 1944: "By reference to the above set out provisions of the Act of May 25, 1926 (44 STAT. 649, 650, 43 U. S. C. 423e) the so-called excess land provisions of the Reclamation Law are complied with if a water users' organization agrees ( 1 ) to an appraisal of excess irrigable land and (2) to refuse water to excess irrigable lands where the landowner refuses to execute a recordable contract for the sale of said excess irrigable land. There is nothing in the statute prohibiting the furnishing of water to non-excess land. Accordingly, if a landowner refuses to execute a contract for the sale of his excess 40 irrigable acres, the water users' organization is not required to refuse water to his remaining 160 acres."

In giving weight to these administrative interpretations, the opinion relied on Brooks v. Dewar, 313 U.S. 354, 360, 361 (1941); United States v. Hammers, 221 U.S. 220, 228 (1911); Wells v. Nickles, 104 U.S. 444, 447 (1881); People v. Southern Pacific Co., 209 Cal. 578, 290 Pac. 25, 32 (1930) ; Prichard v. Southern Pacific Co., 9 Cal. 
opinion received the formal concurrence of the Chief Counsel of the Bureau and the Solicitor of the Department of the Interior, and administrative policy and action in pursuance of all of the legal conclusions which it embodied were formally adopted and directed by the Secretary of the Interior August 25, 1945..$^{2}$ All of the water service contracts in the Central Valley Project therefore have been negotiated or are being negotiated on that basis.

\section{Community Property}

One of the first questions raised in the early negotiation of fortyyear water service contracts in the Central Valley Project was that of the relation between the acreage limitation provisions of the federal reclamation laws and the community property laws of Califor-

App. 2d 704, 51 P.2d 428, 429 (1935). Additional reliance could have been placed on United States v. American Trucking Associations, 310 U.S. 534, 549 (1940) ; Norwegian Nitrogen Products Co. v. United States, 288 U. S. 294, 315 (1933).

72 The opmion was addressed to four separate questions involving the acreage himitation provisions of the federal reclamation laws. An ancillary question is presented in the situation of one who owns land in more than one contracting district. On February 13, 1948, a subcommittee, consisting of four lawyers and one engineer, of the Statewide Committee on Utilization and Control of Water Resources, of the California State Chamber of Commerce, rendered a summary report of its views to the Committee on the status of lending agencies under the acreage limitation provisions of the federal reclamation laws. In concluding its submittal to the Committee, which was widely disseminated by the Water Economics Committee of the Irrigation Districts Association of California as No. 8 of a series of pamphlets, the subcommittee volunteered an additional comment: "In your letter you use the expression: 'when they become owners of more than 160 acres in an irrigation district which is receiving water from a Federal reelamation project.' [Emphasis added.] In our opinion, the territory to be considered is that within the entire project and not the more limited area comprised within an irrigation district or represented by a water users' association, either of which may be one of a number of similar organizations operating within a single project. This is notably true of the Central Valley Project."

As far as is known, this point bas not expressly received any authoritative and definitive consideration, either by way of legal opinion or judicial decision. But, since Section 46 of the Omnibus Adjustunent Act speaks only in terms of the provisions required to be included in contracts between the United States and individual irrigation districts, it nray be suggested that, as a matter of law, a single person may own and may receive project water for 160 acres in each of several districts. It commonly escapes notice that the proscription is not one by the Federal Governunent on an individual landowner; it rather is a congressional mandate to a federal officer to insist on the inclusion, in a contract between an irrigation district and the United States, of certain provisions. So, it is suggested that the test is one of breach of contract. If $A$ owns 160 acres of land in District $X$ and 160 acres of land in District $Y$, and each district has a contract with the Umited States, by which it agrees to deliver no project water to more than 160 acres in a single ownership, it niay be questionable whether the result is open to successful legal challenge, which presumably would have to be by way of a suit by the United States against one of the contracting districts. 
nia. ${ }^{73}$ This was the question, stated most simply: Is 320 irrigable acres in the ownership of the community "irrigable land held in private ownership by any one owner in excess of one hundred and sixty irrigable acres," in the words of Section 46 of the Omnibus Adjustment Act, or does it constitute two "private ownerships" of 160 acres each?

This question was first expressly presented in 1945, during the negotiation of the Southern San Joaquin Municipal Utility District contract. ${ }^{74}$ Provisions recognizing joint tenancies, tenancies in common, and tenancies by the entirety were found to have been included in contracts executed in other reclamation projects. ${ }^{75}$ Also, it long before had been held by the Department of the Interior that, in determining the eligibility of a homestead applicant who already owned lands in common with others, the applicant should be charged only with that portion of the total acreage held in common which was in ratio to his fractional interest. ${ }^{76}$ This departmental decision was inlplemented by a Circular Letter of the Bureau of Reclamation, which provided: ${ }^{\pi \tau}$

Therefore, in determining the acreage for which one, having an undivided imterest in land irrigable under any reclamation project, may make and have accepted a water right application he shall be charged with that portion of the total irrigable acreage owned by him in common with others which is represented by the fractional extent of his undivided interest. [Emphasis added.]

At this point it seemed clear that, if the title to land held as coinmunity property was acquired subsequent to July 29, 1927, the interest of each of the spouses constituted a "private ownership," within the meaning of Section 46 , and hence that a husband and wife owning 320 acres of land as community property were eligible to receive project water for the entire 320 acres. The significance of the 1927 date lies with Section 161a of the California Civil Code, which declares the interests of husband and wife in community property to be "present, existing and equal interests under the management and control of the

73 CAL. Crvir. CODE $\$ \S 161$ et seq.

74 Supra note 70.

${ }^{75}$ See, e.g., Article 30 of contract between United States and Jefferson Water Conservancy District, Deschutes Project, Oregon, dated January 4, 1938; Article 29(a) of contract between United States and Lugert-Altus Irrigation District, W. C. Austin Project, Texas, dated January 12, 1942.

76 DeWolf v. Moore, 37 L.D. 110 (1908).

77 Circular Letter No. 565, June 13, 1916. 
husband ...."A question remained, however, whether the same conconclusion would be applicable in instances in which title to the community property had been acquired prior to July $29,1927 .^{78}$

Examination of the California statutes enacted over a period of years, some of them prior to the 1927 statute, indicated that the wife was given such elements of equitable ownership and control of the community property as to justify regarding her interest as one "owned ... in common" within the meaning of Circular Letter No. 565. For example, she could in some limited circumstances obtain a divison of the property without a dissolution of the marriage, ${ }^{79}$ a fact which likened her interest somewhat to that of a joint tenant or a tenant in common. The husband could not always convey the property without the wife's joinder in the conveyance. ${ }^{80}$ The wife possessed a testamen-

78 The reasons for this question were well identified in the opinion of the United States Supreme Court in Commissioner v. Harmon: "Our decisions in United States v. Robbins, 269 U.S. 315, and in United States v. Malcolm, 282 U.S. 792, do not, as respondent argues, require an affirmance of the judgment. Those cases dealt with the community property law of California. The concept of community property came to California from the Spanish law, as it did in other States whose territory had once been a part of the Spanish possessions on this continent. There had been a series of decisions in California with respect to the character of the wife's rights in the community. The courts had at times indicated that this was a vested property right and on other occasions had indicated that all the wife had was a mere expectancy which ripened on the death of the husband. Prior to the decision in the Robbins case the Supreme Court of the State had finally ruled that her interest was of the latter sort. The Treasury had taken the same view and had denied California spouses the privilege of each returning one-half of the commumity income. In view of the decision of the Supreme Court of California this court sustained the Treasury's ruling in the Robbins case. This was in spite of the fact that over a period of years the legislature of California had adopted statutes which indicated that the wife's interest was in fact more than a mere expectancy. In 1927 the California legislature, in an effort to settle this controversy of long standing, adopted a statute declaring that the wife's interest in the community was a present vested interest. Then came the Malcolm case in which the Circuit Court of Appeals for the Ninth Circuit certified to this court two questions: First, whether in view of the law of California the husband must return the entire income, and second, whether the wife, under the Act of 1927 , had such an interest in the community income that she should separately report and pay tax on one half thereof. In a per curiam opinion this court answered the first question 'No' and the second question 'Yes.' Two circumstances must be borne in mind in connection with that decision. The incidents of the system had been the subject of litigation for years. The final action of the legislature could well be taken as declaratory of what it involved and implied as respects the interests of husbands and wives . . . ." [Emphasis added.] 323 U.S. 44, 48-49 (1944).

79 Cad. Crv. Code $\$ 137$.

80 Cax. Crv. Code $\$ 172$ a. 
tary power with respect to the property which was commensurate with that of her husband. ${ }^{81}$

All of this led to the conclusion that water legally might be delivered to 320 acres of land held by a husband and wife in California as community property. This conclusion was embodied in an opinion, dated August 1, 1945, in which the Chief Counsel of the Bureau and the Solicitor of the Departnent of the Interior recorded their concurrence, ${ }^{82}$ and admimistrative action pursuant to it was directed by the Secretary of the Interior August 25, 1945.

This should be an adequate response to the criticism that the conclusion was one of expediency, founded in the onerousness of enforcement of the law. The Federal Government merely has recognized and has followed the state law. That this recognition may place a husband and wife in California in a more advantageous position under the federal reclamation laws than a husband and wife in a non-community property state is no more curious than the advantage the same couple enjoyed under the federal income tax laws prior to the 1948 amendment of Section $51(\mathrm{~b})$ of the Internal Revenue Code, ${ }^{83}$ and for the same reason.

81 CaL. Probate Code $\S \S 201-203$. Very shortly before the enactment of the 1927 statute, the Supreme Court of California had said, in Stewart v. Stewart: "We wish to say in conclusion that we are in accord with the intimations from time to time reflected by this court in the long line of its past decisions to the effect that the interest of the wife in the property of the community during the continuance of the marriage rclation, while it has not yet reached the status of a vested interest therein, is, and has always been from a time reaching back into the Spanish and Mexican origins of our commumity property laws, a much more definite and present interest than is that of an ordinary heir. She has, by virtue of the share which in her own sphere sle has contributed toward the acquisition and conservation of such properties, rights therein which have been always safeguarded against the fraudulent or inconsiderate acts of her husband with relation thereto, and for the assertion and safeguarding of which she las been given access to appropriate judicial remedies both before and after the time when her said rights and interests would ripen and become vested through the death of the husband or other severance of the marriage relation, whenever such rights and ultimate interests were affected by or threatened with such forms of invasion ...." 199 Cal. 318, 249 Pac. 197, 207 (1926).

82 This particular question shortly thereafter was the subject of a separate opinion by the Solicitor of the Department of the Interior, in which he adhered to his previous concurrence. Solicitor's Opinion M.34172, August 21, 1945. The Solicitor said: "It is iny opinion that an administrative determination that 320 acres of irrigable lands can be held in community ownership is a reasonable coustruction of the excess land provisions of the Federal Reclamation Laws."

8362 STAT. 115 (1948). 


\section{Commingled Water.}

A question of the extent of the applicability of Section 46 to the delivery of water which is a product of the commingling of project water and water from another source was presented in 1949, during the negotiation of a forty-year water service contract with the Tulare Irrigation District.

The question arose out of this physical situation: The Friant-Kern Canal is the conduit by which water will be carried from Friant Reservoir, a total distance of 153 miles to the south, for delivery to a number of contracting districts enroute. The canal siphons across the Kaweah River at a point approximately seven miles from the boundary of the Tulare Irrigation District. In lieu of constructing separate works through which project water would be conveyed from the canal to the district boundary, for ultimate delivery through the district's existing distribution system, it was proposed to divert project water directly into the channel of the Kaweah River. The district already has established rights to the use of a portion of the natural flow of the Kaweah River, but these rights are at times inadequate for its entire needs. At such times during the irrigation season as the district should simultaneously be enjoying its natural flow rights and be receiving project water through the channel of the Kaweah River there would be an inevitably mingled corpus of water.

The question presented, therefore, was: Would the delivery of water, a portion of which was originally project water, to excess lands in itself constitute a violation of the contractual provisions required by Section 46 of the Omnibus Adjustment Act? Or, would there be adequate compliance if in fact the amount of water delivered to nonexcess lands should at least equal the amount of project water diverted from the Friant-Kern Canal into the Kaweah River? In short, does Section 46 embody a requirement which is immutably qualitative, or may it be quantitative?

Section 46 provides that "no such excess lands so held shall receive water from any project...." If construed strictly and technically, this could mean that the introduction of a negligible amount of project water into a large supply derived from a private source before its application to the land would foreclose the delivery of any water to excess lands. On the other hand, it was not open to denial that the requirements of Section 46 would be satisfied in the Tulare situation if the corpus of the project water were to be kept separated, so that none of it could reach excess lands. To do this, however, would have involved 
an unnecessary conduit, generally parallel to the Kaweah River, and an unnecessary duplication of the district's existing distribution system, the cost of all of which would run into millions of dollars and would have to be repaid by all of the landowners. Yet no water user, whether an excess-land owner or a non-excess-land owner, would receive any greater or any less benefits-he simply would have the dubious comfort of knowing that his water was either Kaweah River water or Friant Reservoir water, and not an indistinguishable mixture of both. ${ }^{84}$

Project water has no unique physical characteristics which differentiate it from other water. ${ }^{85}$ If the purpose and intent of the law are accomplished it makes no significant difference if the molecular corpus of some project water finds its way to excess lands so long as an equivalent amount of water is utilized on non-excess lands. No more water will in fact have been delivered to excess lands than would have been legally available to them had there been no project supply.

The state law tends to lend a hand at this point in resolving the question. A California statute provides: ${ }^{86}$

Water which has been appropriated may be turned into the channel of another stream, mingled with its water, and then reclaimed; but in reclaiming it the water already appropriated by another shall not be diminished.

84 At this point, the obvious reference is to the familiar principle that statutes are to be given a sensible construction, and not one leading to absurd results. United States v. American Trucking Association, 310 U. S. 534, 542-544 (1940) ; Haggar Co. v. Helvering, 308 U.S. 389, 394 (1939); United States v. Ryan, 284 U.S. 167, 175 (1931); United States v. Kirby, 7 Wall. 482, 486-487 (1868); SuTHĖrLAND, STATUTORY ConSTRUCTION $\$ 5505$ (3d ed. 1943). And no conclusion on what the words "no such excess lands so held shall receive water from any project" mean, in the factual situation wbich has been described, should be reached without a consciousness of Mr. Justice Holmes' immortal statement in Towne v. Eisner: "A word is not a crystal, transparent and unchanged, it is the skin of a living thought and may vary greatly in color and content according to the circumstances and the time in whicb it is used." 245 U.S. 418, 425 (1918). Also, "delusive exactness is a source of fallacy throughout the law," Truax v. Corrigan, 257 U.S. 312, 342 (1921).

85 This statement imvolves an intentional assuniption, but one which is reasonably sound in fact. The above discussion is not intended to embrace a potential situation in which the operation of the project may be alleged to have impaired the quality of the water which a water user would have been able to put to beneficial use under natural conditions. Such a situation of course would present various avenues of relief. While the possibility of its development at some point in the operation of the project is not to be dismissed, it is not understood to be present in the Tulare situation.

80 Cal. WATER CODE $\$ 7075$. 
A more vivid judicial description of the legal and practical futility of ascribing molecular magic to mingled waters appears in the opinion of the District Court of Appeals of California in Los Angeles $v$. Glendale: ${ }^{87}$

One who is shown to have title to a definite amount of water, which becomes combined with other water of like physical properties, may abstract from the combined body of water an amount equal to that which he put in; the fact that he cannot identify it as the precise water which was his does not matter ... . But one who has no title to any of several distinct sources of water as they combine - to make a single supply, in the nature of things is unable, as he takes from that supply, to establish that he is taking water of any particular source.

Finally, a nice physical and financial analogy to the Tulare situation was presented in Los Angeles $v$. Glendale, in which the court said: ${ }^{88}$

Plaintiff had a prior right to the use of the water brought to the San Fernando Valley. It did not abandon that right when it spread the water for the purpose of economical transportation and storage. It used a similar storage system at the source of this supply in the Owens River Valley. By availing itself of these natural reservoirs, it spared its citizens the cost of financing the construction of additional dams, if, indeed, appropriate sites were available at the lower end of the aqueduct. Early in the history of the state, this court recognized the advantage of permitting the use of natural surface facilities, stream beds, dry canyons and the like, for the transportation of water ... for "It would be a hàrsh rule ... to require those engaged in these enterprises to construct an actual ditch along the whole route through which the waters were carried, and to refuse them the economy that nature occasionally afforded in the shape of a dry ravine,.gulch, or canon." Hoffman v. Stone, $7 \mathrm{Cal}$. at page 49.

All of this, when put together with the early but consistent expressions of the Congress, ${ }^{89}$ led to a conclusion that the proposed contract would not be violative of Section 46 of the Omnibus Adjustment Act. However, two apparently contrary opinions of the Solicitor of the Department of the Interior rendered some years before, ${ }^{90}$ on similar but

87132 P.2d 574, 586 (1943).

8823 Cal. 2d 68, 142 P. 2d 289, 294 (1943).

89 REv. STAT. $\$ \$ 2339,2340$ (1875), 43 U.S. C. $\$ 661$ (1946) ; Section 1 of Desert Land Act, 19 STAT. 377 (1877), 43 U.S. C. $\$ 321$ (1946); Section 8 of Reclamation Act of 1902, supra note 2, 43 U.S. C. $\$ 383$ (1946).

${ }^{80}$ Solicitor's Opinion M.21709 (Marcl 3, 1927); Solicitor's Opinion M.22401 (June 14, 1927). 
possibly distinguishable facts, remained outstanding. The question presented by the proposed Tulare contract therefore was referred by the Secretary of the Interior to the Solicitor for a ruling. The Solicitor concluded: ${ }^{01}$

... I am confident that, when this statutory language [Section 46] was enacted, the legislators did not have in mind a situation where, as a means of transporting project water, it is to be turned into a river and commingled with river water in which the members of an irrigation district have rights independently of the reclamation laws and to which they have access without regard to the reclamation project, and where there will be no possible way of identifying the project water and of distinguishing it from the other water as of the time when the commingled water reaches the lands within the district ....

I believe that, in the unusual situation with which we are dealing here, a reasonable argument can be made to support the view that only so much of the commingled water as represents the quantity of water supplied by the Bureau of Reclamation must necessarily be regarded as project water for the purpose of the 160-acre limitation. Therefore, I have concluded that it would not be necessary to disapprove the proposed plan on legal grounds if it should be deemed advisable, from the standpoint of policy, to enter into such an arrangement....

As finally approved by the Department of the Interior, the contract contains provisions which both recognize the quantitative concept of "project water" and establish mechanics of measurement insuring compliance with the principle of the acreage limitation. ${ }^{92}$

${ }^{91}$ Solicitor's Opinion M.36011 (September 23, 1949).

22 Article 32 of the contract provides: "(a) The provisions of this contract shall not be applicable to or affect water or water rights now owned or hereafter acquired by the District other than from the United States. Water furnished by the United States to the District pursuant to this contract nuust of necessity be transported by the District from the points of dehvery established pursuant to Article 13 of this contract by nieans of the same works and channels as water now owned, or which may hereafter be acquired, by the District other than pursuant to the ternis of this contract. Notwithstanding sucls mingling of water, the provisions of this contract shall be apphicable to the quantity of water furnished to the District pursuant to the terms hereof, and such mingling of water shall not in any manner subject to the provisions of this contract the quantity of water acquired by or available to the District other than from the United States.

"(b) The District will provide and maintain separate outlets from its distribution system for nonexcess land and excess lands as defined in Article 26. At the request of the contracting officer the District will install, operate and nuaintain water neasuring equipment at delivery points to excess lands and, further, will install similar equipment for measuring the water available to the District other than from the Project and the contracting officer may check and inspect said equipment at any time.

"(c) The District agrees that the quantity of water furnished to it by the United 


\section{Applicability to Use of Project Water on Private Lands}

It frequently has been asserted that the acreage limitation provisions either do not, or should not, apply to lands in private ownership, that their original intent was to limit the amount of public land and water that a settler might obtain, that their application to developed lands is confiscatory, and that, in the Central Valley, they are unenforceable because of the underground water situation.

It is clear that as a matter of law they do apply to the use of water on lands in private ownership. Section 5 of the original Reclamation Act of $1902^{33}$ expressly provided that "no right to the use of water for land in private ownership shall be sold for a tract exceeding 160 acres to any one landowner ...." During the course of congressional debate Representative Mondell, of Wyoming, stated: ${ }^{\text {o4 }}$

Under nearly every project undertaken by the Government there will undoubtedly be some lands in private ownership; and it would be manifestly unjust and inequitable not to provide water for those lands, providing their owners are willing to comply with the conditions of the Act; and in order that no such lands may be held in large quantities or by nonresident owners, it is provided that no water right for more than 160 acres shall be sold to any landowner, who must also be a resident or occupant of his land. This provision was drawn with a view to breaking up any large land holdings which might exist in the vicinity of Government works and to insure occupancy by the owner of the land reclaimed.95

States during each 24-hour period will be delivered by the District only to nonexcess land, through the aforesaid outlets to nonexcess lands, or to spreading basins. The District shall be deemed to be in breach of Articles 24, 25, and 26 of this contract if at any time there is furnished to all excess lands a quantity of water which is greater than that which the District would have had available to it for furnishing to all land within the District in the absence of the Project supply furnished by the United States pursuant to this contract."

93 Supra note 63.

9435 CoNG. REc. 6678 (1902).

95 In 1904, Senator Newlands, of Nevada, who was one of the sponsors of the Reclamation Act, said: "As to the lands now in private ownership and coming within the proficient operation of this Act it is provided that no water rights can be granted to any proprietor of land within reach of an irrigation project for more than 160 acres. He may have $10,000,50,000,100,000$ acres, but he can only secure water right from the government for 160 acres. But you say, that is unjust to him and injurious to the country's development, that it condemns this entire area in single ownership to aridity. Not so. The fact that waters from the irrigation project can be brought within the reach of this large holding raises its value. Purchasers of that holding in tracts of 160 acres can secure water rights under this Act. The large landed proprietor is benefited by having the water brought within reach. He has the opportunity of making sales of lands hitherto unsalable and a purelaser can unite the water with the land by buying a water right from the government and thus dedicate the land to further productiveness and so that act not only guarantees against monopoly in the state but will gradually destroy existing monop- 
This national policy laid down by the Congress has remained constant throughout the evolution of the federal reclamation laws and efforts to bring about its legislative abandonment have been unfruitful.

As for the application to the Central Valley Project of this policy, no less than eighteen separate enactments of the Congress, beginning with the Emergency Relief Appropriation Act of $1936,{ }^{96}$ and including the 1937 act expressly authorizing the Central Valley Project, ${ }^{97}$ have expressly recognized that the Central Valley Project is authorized, being constructed, and will be paid for under the provisions of the federal reclamation laws. ${ }^{9 s}$ To say that its operation is to be relieved of the provisions of those laws would seem tenuous, indeed.

Proponents of the law rest heavily on the principle of the familysized farm. This principle has just been shown to have a substantial foundation in the long established policy for the distribution of nationally owned natural resources, laid down by the Congress. A corollary principle, less ideological than financial, is mentioned less frequently than its validity justifies. That is that the funds with which reclamation projects are constructed are advanced, without interest, by the taxpayers of the entire country. The rationale of the application of the acreage limitation to privately owned lands is that this subsidy should be distributed equitably. In short, the taxpayer in New Jersey who is contributing to the bringing of benefits to an owner of 160 acres of land in California or Nevada should not be expected to contribute ten times as much to an owner of 1,600 acres.

It long has been contended by the opponents of the law in the Central Valley that it in fact is unenforceable by reason of the underground water situation, in which, it is alleged, the non-complying

oly and distintegrate these holdings in the country without injury to any and to benefit to all." Ofricial Proceedings of the National Irrigation Congress 34 (1904).

The next year F. H. Newell, the first head of the Reclamation Service, said: "The object of the Reclamation Act is not so much to irrigate the land as it is to make homes. President Roosevelt in his message to this Congress today, and in every previous message to this Congress and to the Congress of the United States, has emphasized again and again that the primary object of the law was to make homes. It is not to irrigate the lands which now belong to large corporations, or even to small ones; it is not to make these men wealthy; but it is to bring about a condition whereby that land shall be put into the hands of the small owner, whereby the man with a family can get enough land to support that family, to become a good citizen, and to have all the coinforts and necessities which rightfully belong to an American citizen." Offictal Proceednags of THE National IRRIGATION CONGRESS 28 (1905).

9649 STAT. 1608 (1936).

9750 STAT. 844 (1937).

93 See text supra at note 27. 
excess-land owner will pump from underneath his own land water which was paid for by and applied to the surface of the lands of his neighbors. The monotonously dinning chant of "unenforceability" reached a point at which even the proponents forgot to take note of the fact that the matter had not yet been subjected to the pragmatic test of actual operation. No technician has had the professional temerity to advance an unequivocal prediction of the detailed hydrological effect of the introduction of a new water supply into an area undergoing depletion. The project is approaching the full operation stage and it would seem reasonable to permit the existing law a factual trial in the controversial area, and thereafter to appraise the practicability of its application and retention.

Even assuming, however, that the position of the non-complying landowner is enhanced by a replenishment of his underground water supply through project operation, it need not follow, as a matter of law, that he thereby will have a "free ride," as is so often alleged, at the expense of those who are paying for project water. There is authority in other jurisdictions for the proposition that an owner of excess lands may be assessed by an irrigation district for the benefits he receives by reason of the availability of project water..$^{90}$ The precise question does not appear to have been passed upon by a Califorma court, but the reasoning einployed by other courts is worthy of examination under California statutory law. ${ }^{100}$

\section{Status of Water Service and Repayment Contract Negotiations}

A total of eighteen irrigation districts in the service areas of the Friant-Kern and Madera Canals have contracted or are negotiating for water service contracts, or a combination of water service and distribution system contracts. The following reflects the status of these contracts as of October 2, 1950, in a progressive order of their processes: Three were still in a negotiation stage; two had been approved by the contracting districts as to form; three had been approved by the Secretary of the Interior as to form; three had been approved by the California Districts Securities Commission; three had been executed by both the districts and the United States; four

${ }^{90}$ Shoshone Irrigation District v. Lincoln Land Co., 51 F.2d 128 (D. Wyo. 1930); Nampa \& Meridian Irrigation District v. Petrie, 28 Idaho 227, 153 Pac. 425 (1915); In re Goshen Irrigation District, 42 Wyo. 229, 293 Pac. 373 (1930).

100 For a comprehensive discussion of this problem, see statement and memorandum brief of Chief Counsel of Bureau of Reclamation in Hearings before Subcommiltee of Commiltee on Public Lands on S.912, 80th Cong., 1st Sess. 1270-1290 (1947). 
had been validated by superior courts. All of the contracts contain provisions in compliance with Section 46 of the Omnibus Adjustment Act of 1926.

POWER

\section{Power Features of the Central Valley Project}

The role of power in the Central Valley Project and its attendant legal problems perhaps can be understood best when discussed in the light of the actual and potential physical features of the project that are devoted to power. As indicated previously, ${ }^{101}$ the initial features of the project include electric generating plants at the Shasta and Keswick Dams, a steam electric generating plant, ${ }^{102}$ and an electric transmission system adequate to deliver power fronl points of generation to project pumps and to commercial customers of the bureau. The Shasta facilities have been in operation for several years. The installation there includes five generators having an installed capacity, as indicated by the manufacturer's name plate rating, of 375,000 kilowatts. ${ }^{103}$ The Keswick plant is smaller, having three generators with an installed capacity of 25,000 kilowatts each. Three 230 kilovolt transmission lines, running down both sides of the Sacramento Valley froin Shasta and Keswick to the vicinity of the Tracy Pumping Plant, are under construction and should be completed during 1951. The pumping plant and adjacent switchyard also are planned for completion next year. Construction has not been commenced on the remaining initial Central Valley Project power features, which include a steam plant and transmission facilities to deliver power for commercial sales.

General mention has been made of the power features which were authorized as additions to the Central Valley Project by the Act of October 14, 1949. ${ }^{104}$ Pursuant to this legislation, there is planned a power plant in connection with Folsom Dam, near the city of Folsom, with a capacity of 160,000 kilowatts, as well as an afterbay plant several miles below Folsom, at the Nimbus site. The proposed capacity of this installation is 5,000 kilowatts.

101 See note 31 supra.

102 The question of the authorization of this plant has been the subject of much controversy, especially between the bureau and PG\&E before congressional appropriations committees. See text at notes 129-136 infra.

103 Actually the capability of each generator exceeds the manufacturer's name plate rating by a significant amount-the Shasta generators in fact will produce 90,000 kilowatts each, or a total of 450,000 kilowatts.

${ }^{104}$ See text at notes 28-30 supra. 
The picture would be incomplete without mention of some of the . nnajor units included in the plan of the Department of the Interior for the coniprehensive developinent of the water resources of the Central Valley Basin. ${ }^{105}$ Certain of these proposed features were specifically approved by the President in a letter to the Secretary of the Interior dated August 15, 1949, commenting on the plans of both the Department of the Interior and the Department of the Army and authorizing their transmittal to the Congress. ${ }^{106}$ The hydroelectric facilities approved include: power plants in conjunction with the New Melones Dam on the Stanislaus River and Pine Flat Dam on the Kings River, both presently authorized to the Corps of Engineers, ${ }^{107}$ and one at the proposed Tulloch afterbay dam, also on the Stanislaus River.

Future plans of the bureau for power expansion of the Central Valley Project, in addition to those specifically approved by the President in August 1949, but within the general plan of resource developnient sent to the Congress with his concurrence, include hydro developnents on the American and the Kings Rivers, and facilities on the Kern, the Feather, and the Trinity Rivers. The time and manner in which new facilities may be proposed for construction as additions to the Central Valley Project will depend on the need for power revenues to assist in the financing of additional irrigation features of the project, as well as on the need for power for pumping and commercial sales. Authorization, of course, will depend to a great extent on the disposition of the Congress with respect to public power developnent.

\section{The Power "Subsidy"}

The policy of the Federal Government in the reclamation of the arid areas of the west during the past half century is well known. Not so well recognized, but equally significant is the policy of developing power, as a part of federal reclamation projects, for the dual purposes of providing energy for pumps and other project facilities and, still more important, to provide financial aid in the reclamation program. ${ }^{108}$

105 SEN. Doc. No. 113, 80th Cong., 1st Sess. 5 (1947).

106 See note 30 supra.

107 Flood Control Act of 1944, 58 Stat. 887 (1944).

108 This latter policy had its beginning in the Act of April 16, 1906, 34 STAT. 116, 117 (1906), 43 U.S.C. $\$ 522$ (1946). Section 5 of that act provided: "Tliat whenever a development of power is necessary for the irrigation of lands under any project undertaken under the said reclamation act, or an opportunity is afforded for the development of power under any such project, the Secretary of the Interior is authorized to lease for 
The most recent general statute recognizing this latter policy is the Reclamation Project Act of $1939 .{ }^{109}$ In determining project feasibility under the formula established in Section 9(a) of that Act, the Secretary of the Interior may demonstrate that power revenues are sufficient to return the investment in electric facilities and, in addition, to repay that part of the cost of irrigation features which are beyond the estimated ability of the water users to repay. ${ }^{110}$

This general policy with respect to the use of power revenues on reclamation projects has been adopted in the legislation specifically relating to the Central Valley Project. Section 2 of the 1937 Rivers and Harbors Act"111 expressly provided "for the generation and sale of electric energy as a means of financially aiding and assisting such undertakings and in order to permit the full utilization of the works constructed to accomplish the aforesaid purposes." This language was retained in Section 2 of the 1940 Rivers and Harbors Act, ${ }^{112}$ which reauthorized the Central Valley Project.

The Shasta and Keswick hydro-generating facilities were built and the transmission limes are being built for the purpose of carrying out these authorizations. The costs allocation report for the project, ${ }^{113}$

a period not exceeding 10 years, giving preference to municipal purposes, any surplus power or power privilege, and the moneys derived from such leases shall be covered into the reclamation funds and he placed to the credit of the project from which such power is derived: Provided, That no lease shall be made of such surplus power or power privilege as will impair the efficiency of the irrigation project." [Emphasis added.]

Another significant law enunciating this policy was the Fact Finders' Act of December 5, 1924. 43 STAT. 672, 703 (1924), 43 U.S.C. $\$ 501$ (1946). Subsection I of that act provides: "That whenever the water users take over the eare, operation, and maimtenance of a project, or a diversion of a project, the total accumulated net profits, as determined by the Secretary, derived from the operation of project power plants, leasing of project grazing and farm lands, and the sale or use of town sites shall be credited to the construction charge of the project, or a division thereof, and thereafter the net profits from such soutces may be used by the water users to be credited annually, first, on account of project construction charge, second, on account of project operation and maintenance charge, and third, as the water users may direct. No distribution to individual water users shall be made out of any such profits before all obligations to the Government shall have been fully paid." [Emphasis added.]

10953 Stat. 1187,43 U.S.C. $\$ 485$.

110 The importance of power revenues to assist in paying out the reimbursable portions of new projects is increasing rapidly. This is for two primcipal reasons-the general rise in construction costs and the fact that the remaining water in the west available for capture and rclease for irrigation purposes is becoming more and more expensive to develop. Few, if any, inexpensive, simple project sites remain.

11150 StAT. 844, 850 (1937).

11254 STAT. 1198 (1940).

113 H. R. Doc. No. 146, 80th Cong., 1st Sess. (1947). 
based on 1946 costs, indicated that power would pay $\$ 227,757,693$ of the total estimated cost of $\$ 384,314,000$. Because of increased construction costs the total investment in the project is now estimated to be approxinately $\$ 500,000,000$. Power now will be called upon to bear at least 70 percent of this total.

The manner and circumstances in which power revenues are to be collected and applied have given rise to many complex legal problems. One of the most interesting and difficult of these concerns the interpretation of the requirements of Section 9 (c) of the Reclamation Project Act of $1939^{114}$ with respect to rate schedules. The significant part of this section reads:

Any sale of electric power or lease of power privileges, made by the Secretary in connection with the operation of any project or division of a project, shall be for such periods, not to exceed forty years, and at such rates as in his judgment will produce power revenues at least sufficient to cover an appropriate share of the annual operation and maintenance cost, interest on an appropriate share of the construction investment at not less than 3 percentum per annum, and such other fixed charges as the Secretary deems proper.

Various views as to the proper interpretation of the section were presented to the Solicitor of the Department of the Interior. The principal point of argument can be identified in the following question: Does the section require that the United States not only realize but also retain a "profit" of three percent of the power investment, or may the sum collected by virtue of the three percent interest on investment be applied to the amortization of irrigation costs beyond the ability of the water users to repay? The Solicitor rendered his opinion to the Secretary, ${ }^{115}$ holding that the minimum rate schedule prescribed by 9 (c) must be such as to produce revenues sufficient only to return, in addition to operation and maintenance costs, an amount equal to three percent of the power construction costs, with the proviso that if total revenues thus produced are insufficient to repay all costs allocated to be repaid by power revenues (power investment plus irrigation subsidy, if any) other fixed charges must be included in the rate schedule to produce revenues sufficient to repay such costs. ${ }^{110}$ Irre-

11453 STAT. 1187, 1194 (1939), 43 U. S. C. \$ 485b (1946).

115 Solicitor's Opinion M. 33473, dated, September 29, 1944, Power Rate Schedule for Columbia Basin (Grand Coulee) Project.

116 This opinion has been the subject of repeated discussions in the Congress. Various bills have been introduced which would have the effect of denying its application. E.g., H. R. 1886 and H.R. 1977, 80th Cong., 1st Sess. (1947). 
spective of this opinion, it is the policy of the bureau, followed in the case of the Central Valley Project, to include a true interest component in power rates. In accordance with the Solicitor's opimon the sums collected representing that component are applied toward repaynient of capital costs of irrigation.

\section{Sale of Central Valley Project Power to "Preference Customers"}

Not only, over the years, has the Congress laid down a policy of utilizing power in financial aid of reclamation, but almost concurrently it has made clear the requirement that public bodies be granted a preference in the purchase of electricity produced on reclamation projects. The requirement by no means is confined to reclamation-it has been made to apply to essentially all federally-produced power. ${ }^{11 \pi}$

The preference policy was first specified in a general way in the Act of April 16, 1906, ${ }^{118}$ wherem the Congress, after authorizing the development of power on reclamation projects, inserted the clause, "giving preference to municipal purposes." So far as the Bureau of Reclamation's present operation is concerned, the Congress made manifest its desires by mcluding in Section 9(c) of the Reclamation Project Act of $1939^{110}$ the following language:

That in said sales or leases preference shall be given to municipalities and other public corporations or agencies; and also to cooperatives and other nonprofit organizations financed in whole or in part by loans made pursuant to the Rural Electrification Act of 1936 and any amendments thereof. ${ }^{120}$

The priority to be accorded public agencies represents a potential source of problems in statutory interpretation. Likewise, the more generous administrative policy of preference suggests possible legal questions in resolving the conflicts of interests between customers entitled to statutory preference, as opposed to those asserting preference under the department's policy. Both of these problems arose some months ago when the Sacramento regional office of the Bureau of Reclamation received inquiry regarding power service from a local water com-

11 E.g., 38 StaT. 242, 245 (1913); 41 Stat. 1063, 1067 (1920), as amended, 16 U.S.C. $\$ 800$ (1946); 48 STAT. 58 (1933), 16 U.S.C. $\$ \S 831$ et seq. (1946); 49 STAT. 1363 (1936), 7 U.S.C. \$§ 901-915 (1946); 50 STAT. 731 (1937), 16 U.S. C. \$\$ 832-832e (1946); 52 STAT. 403 (1938), 16 U.S. C. $\S 833-833$; and 58 STAT. 887 (1944).

118 See note 108 supra.

110 See note 114 supra. It is interesting to note in this general connection that the state's Central Valley Project Act also grants preference in the following language: "the authority shall grant preference to State agencies or other organizations not organized or doing business for profit." Cal. Stats. 1933, c. 1042, § 8, CAL. WATER CODE § 11626. 
pany engaged in the distribution of irrigation water. Although the name indicated the organization to be entirely private, an examination of its record of incorporation and inquiry into its methods of operations suggested it might well be classified as a cooperative. Assuming it to be a cooperative, still it was felt that it could not be brought within the meaning of Section 9(c), since it was not "financed in whole or in part by loans made pursuant to the Rural Electrification Act of 1936, or amendments thereof." Nevertheless, it apparently would have come withm the intent of the Departmental order. It was concluded that the Secretary of the Interior was within the proper exercise of his discretion in granting, $m$ effect, an administrative priority to agencies of this type even though they fell outside the legal inclusion of applicable statutes, provided that in the granting of preferential treatment those agencies entitled to statutory preference should be reasonably protected.

The preference problem has given rise to differences of opinion with Pacific Gas and Electric Company to which essentially all of the Central Valley Project power has been sold thus far. The company has taken the position that unless there are in existence preference customers which are able and desire to purchase Central Valley Project power, the bureau legally can sell all of its power under a long term sale to a private utility ready, able, and willing to purchase the power at a fair and reasonable rate. ${ }^{121}$ On the other hand, the bureau has maintained that such a transaction would be illegal and contrary to the expressed purpose of the Congress. The bureau, in relation to sales of Central Valley Project power to Pacific Gas and Electric Company, has insisted on (1) a short term contract, (2) a contract with adequate provision for withdrawal or release of power at specified future dates in order to place the bureau in a reasonable position to serve any preference customers which might apply for service, or (3) a contract

120 On January 3, 1946, the Secretary of the Interior implemented the congressional policy by issuing a staff memorandum on power policy, setting forth certain broad principles to be followed by all Interior Department agencies with respect to the planning, construction, operation, and sale of all electric power which is the responsibility of the department. The program, based as it was on all of the indications of congressional intent as refiected by numerous laws and extended hearings and debate in both houses of the Congress, announced a preference policy somewhat broader than that specifically stated in the Reclamation Project Act of 1939.

121 Company attorneys at one time urged the proposition that the bureau would be required to sell its power to the highest bidder, regardless of the preferential status of any of the bidders. Such a course of action would seem completely to defeat the entire purpose of the preference statutes. 
with "wheeling" or "exchange" 122 provisions under which the company would make deliveries for the bureau to bureau customers. ${ }^{123}$

The bureau and the company also differ as to the intent of the Congress as revealed by these preference statutes in a related aspect of the problem. The bureau takes the view that these statutes are einpty and meaningless unless the Government provides necessary transmission. It is well known that few public bodies are so situated physically or financially that they could build their own transmission lines to sources of hydro-generation. ${ }^{124}$ It seems reasonable, then, to conclude that the Congress intended that the bureau build the transmission lines required to make Shasta and Keswick power practically available to preference customers and not merely in a theoretical sense. Apparently the company believes the statutes are satisfied even if preference sales are limited to those able to build transmission lines to points of generation.

\section{Pacific Gas and Elcctric Company and the Central Valley Project}

The problems between the bureau and the PG\&E are not confined to questions relating to preference customers. No discussion of the Central Valley Project would be complete without reference to its attitude with respect to the construction of the entire project and especially the power features. The historical opposition of the com-

122 "Wheeling" and "exchange" are terms in common use in the electric utility field. "Wheeling" describes a device under which utility $A$ transmits electric power of utility $B$ over its lines and delivers it at another point to $B$ or $B$ 's customers. "Exchange" describes a similar situation where power is traded or exchanged, $B$ turning power into $A$ 's system at point $X$ in return for which $A$ delivers power into $B^{\prime} s$ system or serves $B^{\prime} s$ customers at point $X$.

123 During the war, as an emergency measure, a contract was entered into with the company which contained the following provision: "During the term of this contract, and in order to meet the existing war emergency, the parties agree (without establishing a permanent policy in respect to the disposition of power of the United States) that they will endeavor to carry out the provisions of the Reclamation Law providing that preference to given public agencies and cooperatives in the lease or sale of Government power, ... if, as, and when the occasion may require." Pursuant to the contract, the company was requested to serve the city of Roseville, with which the Bureau had negotiated a service contract. The company refused. The company's president, Mr. Black, later explained to a House subcommittee on appropriations "We could not agree to permit the Bureau to use the Company's system to establish a business for itself as a competitor to the Company." Hearings before the House Committee on Appropriations on Interior Desartment Appropriation Bill for 1948, 80th Cong., 1st Sess. 1315, pt. 3. The wartime contract terminated December 31, 1948. Since that time Shasta and Keswick power has been flowing into the PG\&E system under a "day to day" contract.

124 At present, on the Central Valley Project, the only possible exception to this is the city of Redding located some ten miles from the Keswick switchyard. 
pany to the project, both as a state and as a federal undertaking, is too well known to require recounting here. ${ }^{125}$ It is sufficient to mention a few highlights. A combination of private utilities, in which Pacific Gas and Electric Company perhaps was the most active participant and principal contributor, successfully opposed the Water and Power Act submitted to the California voters by referendum in 1922. ${ }^{126}$ The State's Central Valley Project Act became law in 1933 against the strong opposition of the company. In that same year the Act ${ }^{127}$ was submitted to the voters by referendum and narrowly sustained despite more open opposition by the company. ${ }^{128}$

Subsequent to 1935 , when the project was undertaken by the Federal Government, the company's opposition has been directed not to the project as a whole, but to its power features, particularly the transmission lines and steam plant. For the most part this has taken the form of appearances at appropriation committee hearings of the House and Senate. These hearings are replete with the testimony of the company's president, Mr. James B. Black, and others, urging the Congress to eliminate the bureau's requests for funds to cover the power features of the project. ${ }^{129}$ It has been contended that any transmission lines constructed by the Government in the Central Valley area would duplicate existing company lines, that the public already is being served adequately with low cost power, that the company will purchase all the power produced by the bureau, and that the project will be better off financially if it sells power to the company exclu-

125 For a comprehensive review of this opposition, see MONTGOdrery AND CLAWson, op. cit. supra note 10 .

126 The act would have authorized the State to proceed with the Central Valley Project as a state venture. A special state senate committee to investigate expenditures for and against the measure found that opponents had spent $\$ 501,605.68$ in the campaign as opposed to $\$ 159,990.05$ spent by the proponents. Journal of The Senate, 45 th Sess. (1923).

127 Cal. Stats. 1933, c. 1042 ; Cat. Water Code, Div. 6, pt. 3.

128 Jances K. Brown, PG\&E: A Study of Political Practices, Electric Power AND THE PUBLIC INTERest (Bachelor of Arts thesis, Harvard University, December 1949).

129 Hearings before the House Committee on Appropriations on Interior Department Appropriation Bill for 1947, 79th Cong., 2d Sess. 616, pt. 2; Hearings before the Senate Committee on Appropriations on H.R. 6335, 79th Cong., 2d Sess. 988 (1947); Hearings before House Committee on Appropriations on Interior Department Appropriation Bill for 1948, 80th Cong., 1st Sess. 1312, pt. 3 ; Hearings before Senate Committee on Appropriations on H.R. 3123, 80th Cong., 1st Sess. 1433, 1472, pt. 2 ; Hearings before House Committee on Appropriations on the Interior Department Appropriation Bill for 1949, 80th Cong., 2d Sess. 1901, pt. 3 ; Hearings before the Senate Committee on Appropriations on H.R. 6705, 80th Cong., 2d Sess. 998. 
sively. A similar line of argument has been urged in opposition to a steam plant. These contentions often are supplemented by many of the usual arguments against the development of public power. Principal among these is the well-worn "tax argument," which urges that public power development by the bureau will deprive the local, state, and federal governments of a lucrative source of tax revenue. The fallacy of this position is shown in a recent study entitled Public Power Pays. ${ }^{130}$

Moreover, the opposition of the company to appropriations requested by the bureau for a steam plant has included a sharp argument on the question whether such a plant is authorized. The General Counsel of Pacific Gas and Electric Company recorded his opmion with the House and Senate appropriations committees in 1949 that a steam plant was not included among the features of the Central Valley Project undertaken by the Bureau of Reclamation in 1935, that the construction of such a plant is not authorized by federal reclamation laws and would be unconstitutional. ${ }^{131} \mathrm{~A}$ contrary view has always been taken by the Bureau of Reclamation. ${ }^{132}$ An opinion of the Chief Counsel of the Bureau in exposition of this settled administrative and executive viewpoint was filed with the appropriations committee of the Senate in $1949 .{ }^{133}$ It points out that the Central Valley Project undertaken by the Federal Government in 1935 was essentially the same project as that approved by the State of Califorma in the Central Valley Project Act of 1933, which project included a steam plant, that the construction of a steam plant was encompassed by federal reclamation laws, and was authorized by the language of the Act of August 26, 1937, ${ }^{134}$ and the Act of October 17, 1940, ${ }^{135}$ which reauthorized the Central Valley Project as a federal undertaking. The argument

130 Cartton W. NaU (American Public Power Association, 1948).

131 Hearings before the Senate Committee on Appropriations on H.R. 3838, 81st Cong., 1st Sess. 1843-1846, pt. 2; Hearings before the House Committee on Appropriations on Interior Department Appropriation Bill for 1950, 81st Cong., 1st Sess. 822-826, pt. 2.

132 H. R. Doc. No. 146, 80th Cong., 1st Sess. (1947).

133 Hearings before the Senate Committee on Appropriations on $H . R$. 3838, 81st Cong., 1st Sess. 2529-2539, pt. 2 ; see also, Statement Relative to Authorization for Steam Plant, Central Valley Project, by Secretary Chapman; Hearings before the Senate Committee on Appropriations on Interior Department Appropriation for 1951, 81st Cong., 2d Sess. 1709, pt. 2; Memorandum Re Authorizations for Central Valley Project Transmission Lines and Steam Plant, supplementing statement of Northcutt Ely, Special Counsel for the Water Project Authority of the State of California, id. at 953, 972, pt. 1.

13450 STAT. 844 (1937).

13554 StaT. 1198 (1940). 
with respect to the constitutionality of the steam plant parallels the argument with respect to a "single-purpose power project" which was raised in a recent hearmg before the Federal Power Commission concerning the application of Pacific Gas and Electric Company for a license to construct a certain hydroelectric power project on the Kings River. ${ }^{136}$

This brief review of the company's opposition to the Central Valley Project, particularly its power features, is not for the purpose of further public airing of the differences between the company and the bureau with respect to the Government's public power program. It is mentioned only as a backdrop against which the reader may better understand some of the bureau's problems in the power field. In fact, as of this writing, there are under way between the bureau and the company contract negotiations which would provide for the sale of Central Valley power to the company and at the same time require the company to furnish the bureau "wheeling" or "exchange" service in order that Shasta and Keswick power can be delivered to preference customers. Under the proposed arrangement, the company would provide steam, or support, power as a substitute for the bureau's steam plant. To a considerable extent this appears to be the answer of the Congress to a long-standing controversy. ${ }^{13 \pi}$

\section{THE KINGS RTVER CONTROVERSY}

No discussion of the Central Valley Project would be even reasonably comprehensive without something more than a passing mention of the current Kings River controversy, which has now assumed a quite positive and consistent shape on several fronts.

136 For discussion of this, see Section entitled The Kings River Controversy, infra.

137 The committee on appropriations of the Senate in reporting on the Interior Departunent Appropriation bill for fiscal year 1950, SEN. REP. No. 661; 81st Cong., 1st Sess. 13, did not allow funds for a steam plant or for the transmission lines required for service to preference customers. On this poimt the report reads:

"The decision not to recommend the construction of other transmission lines, the steam plant, and other electric facilities is based upon the assumption that the Pacific Gas \& Electric Co. will negotiate a contract with the Secretary of the Interior in accord ance with the basic principles found in the contract between the Southwestern Power Administration and the Texas Power \& Light Co.

"The committee directs that the Commissioner of Reclamation report to the Senate and House Appropriations Committees by January 1, 1950, on progress made on entering into such a contract with the Pacific Gas \& Electric Co." 


\section{Presently Authorized Federal Development on the Kings River}

Interior Department investigations of the irrigation and power potentials of the Kings River began as early as $1902 .{ }^{138}$ Further investigations led to a feasibility report by the Secretary of the Interior in $1940,{ }^{139}$ which, by compliance with Section 9(a) of the Reclamation Project Act of $1939,{ }^{140}$ had the effect of authorizing the Bureau of Reclamation to construct those features which were found feasible and which were recommended for immediate construction, that is, Pine Flat Dam and Reservoir and Pime Flat power plant. Subsequently, however, by Section 10 of the Flood Control Act of 1944, the Congress expressly authorized the Corps of Engineers, of the Department of the Army, to construct Pine Flat Dam. Coupled with this authorization were certain conditions dealing with local repayment for conservation (irrigation, as distinguished from flood control) benefits. ${ }^{141}$

This authorization brought into controversial play the language of Section 8 of the Flood Control Act of $1944 .^{142}$ The Bureau of Reclamation has taken the view that, under this section, the irrigation uses of Pime Flat Dam and Reservoir are subject to the Federal reclamation laws, including the so-called acreage limitation provisions, and that the bureau (for the Secretary of the Interior) is responsible for the negotiation under such laws of contractual arrangements with the irrigation water users. In brief, the bureau's position is based on the legislative history of Section 8 of the Flood Control Act of 1944, its contemporaneous executive and administrative construction, and its

135 See testimony before Federal Power Commission examiner in the Matters of Fresno Irrigation District, et al., Project No. 1925, et al., Transcript, p. 809, et seq.

139 H. R. Doc. No. 631, 76th Cong., 3d Sess. (1940).

14053 STAT. 1187, 1193 (1939), 43 U.S. C. $\$ 485$ h (1946).

14158 STAT. 887, 901 (1944). The section provides in part: "That the Secretary of War shall make arrangements for payment to the Umited States by the State or other responsible agency, either in lump sum or annual installments, for conservation storage when used: Provided further, That the division of costs between flood control, and irrigation and other water uses shall be determined by the Secretary of War on the basis of continuing studies by the Bureau of Reclamation, the War Department, and the local organizations."

142 Id. at 891 . Section 8 provides that whenever the Secretary of the Army "determines, upon recommendation by the Secretary of the Interior that any dam and reservoir project operated under the direction of the Secretary of War [the Army] may be utilized for irrigation purposes, the Secretary of the Interior is authorized to construct, operate, and maintain, under the provisions of the Federal reclaination laws . . . such additional works in connection therewith as he may deem necessary for irrigation purposes." A subsequent provision of Section 8 is that "Dams and reservoirs operated under the direction of the Secretary of War [the Army] may be utilized hereafter for irrigation purposes only in conformity with the provisions of this section ...." 
legislative confirmation and ratification, all in reliance on certain opinions of the Supreme Court of the Umited States. ${ }^{143}$ The somewhat dispersed opposition to this official position seems to have been headed up through the Kings River Water Association. ${ }^{144}$ Although the controversy continues, construction of Pine Flat Dam and Reservoir is going forward under a schedule that contemplates completion in 1954.

\section{Proposed Federal Kings River Power Development}

Associated with the controversy over the functions of the Bureau of Reclamation and application of reclamation laws to the irrigation uses of Pine Flat Reservoir is the question of who should develop the water-power resources at Pine Flat Dam and upstream in the Kings River Basin. The Balch plant of Pacific Gas and Electric Company on the North Fork Kings River is the only power project in the basin at this time. Further development, including enlargement of the Balch plant, has awaited the construction of Pine Flat Dam and Reservoir

143 For the legislative history, see H. R. REP. No. 1309, SEN. REP. No. 1030, and conference report H. R. REp. No. 2051, all 78th Cong., 2d Sess. (1944); 90 Conc. REc. 9264 (1944).

The Interior Department Appropriation Act, 1947, under the heading "General Fund, Construction," appropriated $\$ 100,000$ to the Bureau of Reclamation for "Kings River project, California." 60 STAT. 348,367 . This amount was agreed upon by a conference committee and represented a reduction in the amount allowed in the bill as passed by the Senate. H. REP. No. 2329, 79th Cong., 2d Sess. 10 (1946). The Senate committee had recognized that the purposes for which the item was requested included "Cost allocations," "Completion of water-use studies," "Economic surveys, including land classification," "Preparation for and negotiation of repayment contracts for irrigation features," and "Power studies." Sen. REP. No. 1434, 79th Cong., 2d Sess. 27 (1946). Similarly, the Interior Department Appropriation Act, 1948, appropriated $\$ 100,000$ to the Bureau of Reclamation for "Kings River project, California." 61 Stat. 460, 475.

These appropriations were made following repeated executive and administrative announcements of the functions of the Secretary of the Interior in effecting repayment arrangements. See, e.g., joint statement of Chief of Engineers and Commissioner of Reclamation issued June 24, 1946, reprinted in part in H. R. Doc. No. 136, 80th Cong., 1st Sess. 10 (1947). The Supreme Court has held on a number of occasions that the appropriation of funds with knowledge of the administrative interpretation of a statute, or action taken under it, constitutes a legislative confirmation and ratification of that interpretation or action. Fleming v. Mohawk Co., 331 U.S. 111, 116 (1947) ; Brooks v. Dewar, 313 U.S. 354, 360-361 (1941) ; Isbrandtsen-Moller Co. v. United States, 300 U.S. 139, 147 (1937); Wells v. Nickles, 104 U.S. 444, 447 (1881).

144 The Kings River Water Association is a loosely organized group of some twenty water-users' entities, which have purported to compact their relative rights to the use of the flow of the Kings River; their agreement is one only among themselves, and, while it is customary for representatives of the Association to claim "ownership" of the Kings River, the agreement obviously is binding only as among its participants, which do not include the United States. The agreement has no judicial blessing, nor is it apparent that any ever has been sought. 
because it will provide storage space for the reregulation of water impounded and later used for the generation of power. This reregulation is essential to avoid interference with asserted rights to the use of Kings River water for irrigation purposes. ${ }^{145}$

It is the position of the Bureau of Reclamation (Secretary of the Interior) that development of the full power potential in the Kings River Basin should be undertaken by the United States as an integrated addition to the Central Valley Project. ${ }^{146}$ This is proposed in the Department of the Interior's Comprehensive Plan. ${ }^{147}$ Ultimate full development would, however, be accomplished in stages.

As already indicated, the Bureau of Reclamation was authorized to construct a power plant at the Pine Flat Dam, as well as to construct Pine Flat Dam, in 1940. However, the bureau has been proceeding on the assunption that the entire authorization was repealed by implication when the Congress authorized construction of Pine Flat Dam by the Corps of Engineers. The Secretary of the Interior's report on the Comprehensive Plan included a recommendation that Pine Flat Dam be transferred, upon completion, to the bureau for operation as an integrated addition to the Central Valley Propect, and that a power plant at Pine Flat Dam be authorized for immediate construction..$^{148}$ Authorization of other features of an initial development, described generally in the Secretary's report, was not recommended for the inmediate future because of the absence of necesary details. ${ }^{149}$ This lack has now been filled. A detailed report on the North Fork Kings River development was submitted to the Congress by the Secretary on March 20, 1950, with a recommendation that it be authorized for construction under the federal reclamation laws as a part of the

145 Demands for power and, hence, water for power production do not necessarily coincide with demands for water for irrigation uses. To accommodate both purposes, water released from upstream power reservoirs must be held in the downstream reservoir and later released in accordance with irrigation water demands.

146 This position is based partly on the need for coordinating operation of Pine Flat Reservoir with the operation of similar structures in the river system of the Central Valley Basin in order to make maximum use of the basin's water resources. It is also based on the need of the Kings River area for additional water supplies which can be supplied only through an extension of the Central Valley Project and because additional power is necessary for the extension of the project.

147 SEN. Doc. No. 113, 81st Cong., 1st Sess. (1949).

148 Id. at 4,11 .

149 Id. at 4, 5. The President stated in his letter of August 15, 1949: "As additional individual proposed projects not now authorized are found feasible on the basis of detailed project reports, they will be approved for authorization in accordance with the Folsom formula ...." 
North Fork Kings Unit, Kings River Division of the Central Valley Project. ${ }^{150}$

\section{Federal Power Commission Proceedings}

Transmittal of the North Fork report to the Congress was made during an advanced stage of proceedings before the Federal Power Commission on applications by Pacific Gas and Electric Company and Fresno Irrigation District for authorizations covering projects in conflict with the development of Kings River proposed by the bureau. ${ }^{151}$ The proposed project works of both applicants require the use of public lands of the United States, as well as the use of Pine Flat Dam and Reservoir. At the present time a decision of the Federal Power Commission on rehearing is awaited..$^{152}$

150 H. R. Doc. No. 537, 81st Cong., 2d Sess., 1950. The features of this development are the Wishon Dam and Reservoir on the North Fork Kings River; Wishon power plant; Haas power development consisting of a diversion dam, tunnel, penstocks, and power plant; the,Balch power development, to be acquired from the PG\&E and enlarged; the Pine Flat power plant; and transmission and substation facilities to distribute the power to the Kings River service area and surrounding territory and to provide the necessary interconnections with the presently authorized Central Valley Project power system.

151 In the Matters of Fresno Irrigation District (Project No. 1925) and Pacific Gas and Electric Company (Projects Nos. 175 and 1988). Fresno Irrigation District, for itself and as trustee for various water users' organizations, is seeking a preliminary permit under Section 4(f) of the Federal Power Act, 41 Stat. 1063 (1920), as amended, 16 U.S.C. $\S 797(f)$ (1946), for power plants at Pine Flat Dam, on Kings River between Pine Flat Dam and the Balch Plant of PG\&E, and at the Haas site, and for a reservoir and power plant at the Wishon site. The district's application stated: "It is contemplated that the applicant and beneficiaries may either acquire the existing Balch development or receive compensation for the benefits thereto from the proposed headwater storage as provided by law." PG\&E's applications, under Section 4(e) and Section 6 of the Federal Power Act, 16 U.S.C. $\$ \$ 797$ (e), 799, sought an amendment of its existing license for the Balch plant (Project No. 175) so as to permit its enlargement, and a license for a project (No. 1988) consisting of the Wishon Reservoir, the Wishon and Haas power plants, the Helms Reservoir, and a power plant on the main stem of the Kings River between Pine Flat Dam and the Balch plant.

152 The commission issued orders authorizing the issuance of (1) a preliminary permit to Fresno Irrigation District for a power plant at the Pine Flat Dam; (2) an amendment of the license held by PG\&E Company for its existing Balch plant so as to permit its enlargement; (3) a license to the company for Project No. 1988 substantially as requested in the application. The orders included conditions (1) requiring the company to subınit evidence satisfactory to the commission of an agreement with local irrigation interests before the license or license amendment would issue, (2) requiring for Project No. 1988 agreement with "the Secretary of the Army or other appropriate officer of the United States for the reservation by the United States of sufficient power storage space in Pine Flat Reservoir to permit reregulation of the stored water released from the licensee's proposed project facilities ...," and (3) requiring reimbursement for such 
These commission proceedings constitute another front in the "Kings River controversy." The question of the respective responsibilities of the Secretary of the Interior and the Secretary of the Army with respect to Pine Flat Dam and Reservoir are, of course, incidentally involved in the commission proceedings by reason of the necessity for use of Pine Flat Reservoir for reregulation of upstream power water releases. ${ }^{153}$ Otherwise, the legal issues in the two controversies appear to be distmct. The principal legal issues in the commission proceedings of official concern to the bureau relate to the jurisdiction and guiding policies of the commission as prescribed in the Federal Power Act, ${ }^{154}$ the limitations, if any, imposed on that jurisdiction by Section 5 of the Flood Control Act of $1944^{155}$ and the effect and validity of certain so-called "first-form reclamation withdrawals" of the public lands of the United States which the applicants seek to use.

The responsibility of the commission under Section 7(b) of the Federal Power Act for recommending federal development clearly cuts across and overlaps the authority of the Secretary of the Interior to recommend and also to undertake development on behalf of the United States pursuant to reclamation laws. Disagreement between the two agencies presents the dual questions of law and administrative policy whether the Federal Power Commision legally can control

storage space reserved either for Project No. 1988 or Project No. 175. A rehearing was granted on application of the Secretary of the Interior. Thereafter, new briefs were filed and oral argument was presented to the Commission.

153 This is reflected in the conditions attached to the commission orders in Project No. 1988, supra note 152 .

15441 Star. 1063 (1920), as amended, 16 U.S.C. \$ 791(a) et seq. (1946). So far as federal development is concerned, Sections $7(\mathrm{~b})$ and $4(\mathrm{e})$ are of the greatest significance. 16 U.S.C. $\$ 800$ (b), 792(e). Section 7(b) provides: "Whenever, in the judgment of the Commission, the development of any water resources for public purposes should be undertaken by the United States itself, the Commission shall not approve any application for any project affecting such development, but shall cause to be made such examinations, surveys, reports, plans, and estimates of the cost of the proposed development as it may find necessary, and shall submit its findings to Congress with such recommendations as it may find appropriate concerning such development." Section 4(e) includes the proviso: "That in case the Commission shall find that any Government dam may be advantageously used by the United States for public purposes in addition to navigation, no license therefor shall be issued until two years after it shall have reported to Congress the facts and conditions relating thereto ...."

155 If construed literally, this section would prevent the commission froin licensing the use of Pine Flat Dan for power purposes. The section provides that "electric power and energy generated at reservoir projects under the control of the War Department and in the opinion of the Secretary of War not required in the operation of such projects shall be delivered to the Secretary of the Interior, who shall transmit and dispose of such power and energy ...." 
or condition the reclamation program and, if it can, whether it should do so. ${ }^{156}$ In this respect, the commission proceedings afford an excellent illustration of one of the deficiencies in federal organization in the water resources development and use field, a matter with which several reports of or for the Commission on Organization of the Executive Branch of the Government ${ }^{157}$ were concerned. The case also demonstrates a need for clarification of federal responsibility for and participation in the development and use of water resources, the accomplishment of which was attempted this year by creation of the President's Water Resources Policy Commission. ${ }^{158}$

In light of this duplication and division of responsibility between the Interior Department and the Federal Power Commission, the Secretary of the Interior has urged the commission (1) to recommend to the Congress, pursuant to Sections 7 (b) and $4(\mathrm{e})$ of the Federal Power Act, that the development of the water-power resources of the Kings River should be undertaken by the United States or, (2) in recognition of the Interior Departınent's responsibility, to forward the matter to the Congress for decision..$^{159}$

Overlapping authority between the commission and the Interior Department also is involved in the matter of use of public lands included in the so-called "first-form reclamation withdrawals." 160 These withdrawn lands are literally subject to the licensing authority of the commission under Section 4(e) of the Federal Power Act. However, this authority is subject to the qualification "that licenses shall be issued within any reservation ${ }^{161}$ only after a finding by the Commission that the license will not interfere or be inconsistent with the purpose for which such reservation was created or acquired, and shall be subject to and contain such conditions as the Secretary of the depart-

156 The thesis that the commission should not be placed in such a position is developed in Lewis, The Role of the Federal Power Commission Regarding the Power Features of Federal Projects, 14 GEo. WASH. L. Rev. 96 (1946).

$15 \%$ Report on the Department of the Interior, and related task force reports, $F . R$. Doc. No. 122, 81st Cong., 1st Sess. 26, 65, 76 (1949); Concluding Report, H. R. Doc. No. 197, 81st Cong., Ist Sess. 65 (1949).

158 Exec. Order No. 10095, 15 FEd. REg. 17 (1950).

${ }^{159}$ See note 151 supra. Brief of Bureau of Reclamation, August 2, 1948; Reply Brief of Bureau of Reclamation, August 21, 1948; Supplemental Brief of Bureau of Reclamation, August 20,1949; Memorandum in Support of Apphication for Rehearing, submitted by the Secretary of the Interior, December 9, 1949; Brief of the Secretary of the Interior, as Intervenor, on Rehearing, March 1, 1950.

160 See note 162 infra.

161 "Reservations", as defined in Sec.3(2), 16 U.S. C. §796(2), include withdrawals. 
ment under whose supervision such reservation falls shall deem necessary for the adequate protection and utilization of such reservation." This provision raises the question whether a license may be issued by the commission where the Secretary of the Interior states that no conditions can be devised for the adequate protection and utilization of the withdrawn lands.

Challenge was made in the commission proceedings to the validity of the reclamation withdrawals under Section 3 of the Reclamation Act of $1902 .{ }^{162}$ That section authorizes the Secretary of the Interior to "withdraw from public entry the lands required for any irrigation works contemplated under the provisions of this act ...." Are the words "irrigation works contemplated under the provisions of this act" broad enough to encompass power facilities to be constructed under reclamation laws? Certainly, Section 3 has always been construed thus broadly by the Bureau of Reclamation. The question is of a kind that continually recurs because of the patchwork basis on which reclamation laws have been passed. ${ }^{163}$ It demonstrates the need for "clarification and codification of the laws pertaiming to the Bureau of Reclamation," as recommended by the Commission on Organization of the Executive Branch of the Government. ${ }^{164}$

An additional argument which was advanced in the Federal Power Commission proceedings, though not extensively argued, related to the statutory and constitutional basis for the proposed North Fork Kings River development, characterized by opponents of the bureau as a "single-purpose power project." This argument appears to assume that physical works for the production and sale or use of power constitute, ipso facto, a single-purpose power project, regardless of their economic, financial, operating, or other relationships to physically separate facilities of unquestionable legality. ${ }^{165}$ This argument may assume significance in the further development of the Central Valley Project in accordance with the Comprehensive Plan. Perhaps, therefore, it is appropriate here to indicate the bureau's position on the question. The Chief Counsel of the Bureau has interpreted Section

16232 STAT. 388 (1902), 41 U.S. C. $\$ 391$ (1946).

163 See note 3 supra.

164 See H. R. Doc. No. 122, note 157 supra, at 36 .

IC5 For discussion of the relationships asserted by the Bureau between the North Fork Kings River development, the Central Valley Project, and the comprehensive plan, spe briefs cited note 159 stupra. The estimated cost of the project was allocated between irigition and power. See the Secretary's report, note 150 supra, at 54, 71. 
9(a) of the Reclamation Project Act of 1939 to provide for authorization of works solely for the production or transmission of power for sale purposes. The bureau has in three instances secured authority to construct works where the entire costs were charged to power. ${ }^{106}$ This is, of course, not to say that the power facilities may not serve other purposes in the comprehensive development of the river basin in which they are located. The constitutionality of any so-called single-purpose power project could be discussed only in its specific factual context. It may be appropriate to suggest, however, that Supreme Court decisions with respect to the power to regulate commerce ${ }^{16 \pi}$ and to provide for the common defense and general welfare ${ }^{16 s}$ provide a solid base for the opinion that the construction of these plants is within the constitutional power of the Federal Government.

\section{Proposed Legislation}

However important for the future development of the water resources of the Central Valley Project may be the resolution of some of the legal questions in the "Kings River controversy," it is possible that the Federal Power Commission proceedings may not provide any of the answers. There is still another front of the "Kings River controversy", the Congress. Bills pending ${ }^{160}$ would integrate with the Central Valley Project a North Fork Kings River development consisting substantially of the features described in the Secretary's report to the Congress. Enactınent of any of the bills would also settle the legal argument concerning the respective roles of the Secretary of the Interior and the Secretary of the Army in relation to Pine Flat Dam and Reservoir. The structure, upon completion by the Corps of Engineers, would be transferred to the Secretary of the Interior for operation as an integrated feature of the Central Valley Project.

166 Davis Dam Project, H. R. Doc. No. 186, 77th Cong., 1st Sess. (1941); Kortes Dam and Reservoir and Power Plant, § 9, Flood Control Act of 1944 and SEN. Doc. No. 191, 78th Cong., 2d Sess. (1944); Heart Mountain power development, H. R. Doc. No. 281, 79th Cong., 1st Sess. (1945).

167 Oklahoma v. Atkinson Co., 313 U.S. 508 (1941) ; United States v. Appalachian Electric Power Company, 311 U. S. 377 (1940).

168 Cleveland v. United States, 323 U.S. 329 (1945) ; Steward Machine Co. v. Davis, 301 U.S. 548 (1937); Helvering v. Davis, 301 U.S. 619 (1937).

169 H.R. 5264, and H.R. 6919, both 81st Cong., 1st Sess. (1949); H. R. 8303, H. R. 8885, and H. R. 9632, all 81st Cong., 2d Sess. (1950). 


\section{CONCLUSION}

It has been the intent of this article to identify only some of the legal problems which have arisen in the planning, construction, and operation of the Central Valley Project and in the advancement of the basin-wide development of which it is the initial portion, and to describe the approach that has been employed and the progress that has been made $\mathrm{m}$ meeting them. In general, the topics discussed have been thought to be those in which the most public imterest has been displayed and which are or have been the most controversial.

There are many other problems and many new ones will arise. 